\title{
Recent advances on Dirofilaria repens in dogs and humans in Europe
}

\author{
Gioia Capelli ${ }^{1{ }^{*}}$, Claudio Genchi ${ }^{2 \dagger}$, Gad Baneth ${ }^{3}$, Patrick Bourdeau ${ }^{4}$, Emanuele Brianti ${ }^{5}$, Luís Cardoso ${ }^{6}$, \\ Patrizia Danesi ${ }^{1}$, Hans-Peter Fuehrer ${ }^{7}$, Alessio Giannelli ${ }^{8}$, Angela Monica lonică9 ${ }^{9}$, Carla Maia ${ }^{10}$, David Modrý ${ }^{11,12}$, \\ Fabrizio Montarsi ${ }^{1}$, Jürgen Krücken ${ }^{13}$, Elias Papadopoulos ${ }^{14}$, Dušan Petrić ${ }^{15}$, Martin Pfeffer ${ }^{16}$, Sara Savić ${ }^{17}$, \\ Domenico Otranto ${ }^{8}$, Sven Poppert ${ }^{18,19}$ and Cornelia Silaghi ${ }^{20,21}$
}

\begin{abstract}
Dirofilaria repens is a nematode affecting domestic and wild canids, transmitted by several species of mosquitoes. It usually causes a non-pathogenic subcutaneous infection in dogs and is the principal agent of human dirofilariosis in the Old World. In the last decades, D. repens has increased in prevalence in areas where it has already been reported and its distribution range has expanded into new areas of Europe, representing a paradigmatic example of an emergent pathogen. Despite its emergence and zoonotic impact, D. repens has received less attention by scientists compared to Dirofilaria immitis. In this review we report the recent advances of $D$. repens infection in dogs and humans, and transmission by vectors, and discuss possible factors that influence the spread and increase of this zoonotic parasite in Europe. There is evidence that D. repens has spread faster than D. immitis from the endemic areas of southern Europe to northern Europe. Climate change affecting mosquito vectors and the facilitation of pet travel seem to have contributed to this expansion; however, in the authors' opinion, the major factor is likely the rate of undiagnosed dogs continuing to perpetuate the life-cycle of $D$. repens. Many infected dogs remain undetected due to the subclinical nature of the disease, the lack of rapid and reliable diagnostic tools and the poor knowledge and still low awareness of $D$. repens in non-endemic areas. Improved diagnostic tools are warranted to bring $D$. repens diagnosis to the state of $D$. immitis diagnosis, as well as improved screening of imported dogs and promotion of preventative measures among veterinarians and dog owners. For vector-borne diseases involving pets, veterinarians play a significant role in prevention and should be more aware of their responsibility in reducing the impact of the zoonotic agents. In addition, they should enhance multisectorial collaboration with medical entomologists and the public health experts, under the concept and the actions of One Health-One Medicine.
\end{abstract}

Keywords: Dirofilaria repens, Vector-borne infections, Mosquitoes, Zoonosis, Emergent parasite, One Health

\section{Background}

Amongst mosquito-transmitted nematodes with a zoonotic potential, Dirofilaria repens and Dirofilaria immitis (Spirurida: Onchocercidae) play significant roles from a public health perspective. Dirofilaria immitis causes a severe disease (heartworm disease) in dogs and other carnivores and occasionally infects humans, while $D$. repens usually causes a non-pathogenic subcutaneous

\footnotetext{
* Correspondence: gcapelli@izsvenezie.it

${ }^{\dagger}$ Gioia Capelli and Claudio Genchi contributed equally to this work.

${ }^{1}$ Laboratory of Parasitology, National reference centre/OIE collaborating centre for diseases at the animal-human interface, Istituto Zooprofilattico Sperimentale delle Venezie, Legnaro, Italy

Full list of author information is available at the end of the article
}

infection in dogs and it is the principal agent of human dirofilariosis in the Old World [1].

Dirofilaria repens Railliet \& Henry, 1911 (subgenus Nochtiella) is endemic in many countries of the Old World [2] and affects domestic and wild canids [3]. In these hosts, the adult worms are usually beneath the skin, in the subcutaneous tissues, whereas microfilariae circulate in the blood stream and are ingested by several species of competent mosquito vectors during their blood-feeding.

Microfilaremic dogs are the most important reservoir of infection, with wild canids and domestic and wild felids rarely positive for circulating microfilariae [3, 4]. In humans the parasite does not usually reach the adult

(c) The Author(s). 2018 Open Access This article is distributed under the terms of the Creative Commons Attribution 4.0 International License (http://creativecommons.org/licenses/by/4.0/), which permits unrestricted use, distribution, and 
stage and remains confined to an immature form. It may cause a larva migrans syndrome and form subcutaneous nodules. The worm often reaches the ocular region and occasionally other organs, such as the lungs [1, 5-7].

In the last decades, $D$. repens has increased its prevalence in areas where it has already been reported and its distribution range has expanded into new areas of Europe, with new clinical cases in both dogs and humans increasingly reported [7-11]. Thus, D. repens can be considered as a paradigmatic example of an emergent pathogen.

Despite its emergence and zoonotic impact, $D$. repens has received less attention by scientists compared to $D$. immitis. A thematic search in PubMed (accessed 1st May 2018) of papers focused on D. repens only (repens and NOT immitis in title/abstract and vice versa), resulted in approximately one fifth of the number of publications compared to D. immitis (i.e. 345 vs 1817). Consequently, many aspects of $D$. repens infection and epidemiology are still poorly known, for example its pathogenicity, geographical distribution, therapy and genomics.

In this paper we review the recent advances of $D$. repens infection in dogs, humans and transmission by vectors, and discuss possible factors that influence the spread and increase of the prevalence of this zoonotic parasite in Europe.

\section{History of Dirofilaria repens in dogs and humans}

The first observation of $D$. repens was likely reported in a human being in 1566 by Amato Lusitano, a Portuguese medical doctor, who stated in his Curationum Medicinalium Centuriae "puella trima ... per oculi internam partem, quam angulum magnum appellamus, a jumbrici cuius dam caput appere coepis..." (in a 3-year-old girl, in the area we call big angle of the eye, suddenly it started to appear the tip of one worm which sometimes is sited in the eye making its opacity) [12]. Between 1864-1879, three reports were published in Europe (Italy and Hungary) on subcutaneous and ocular human infections (reviewed in [13]), before Addario's paper on Filaria conjunctivae [14], later considered synonymous with $D$. repens [15]. Ercolani [16] demonstrated that when no worms are found in the heart of microfilaremic dogs, they are usually present in subcutaneous connective or in other sites of the body, suggesting that two species of Dirofilaria were involved in canine filarial infections. Filarial larvae of $D$. repens collected from dogs captured in the Roma area (Italy) as well as in mosquitos were most likely described by Fulleborn [17], although at that time there was a notable uncertainty in the classification of filarial worms obtained both from the subcutaneous tissues of dogs and from ocular localization in humans. For instance, "fully developed" filariae in subcutaneous tissue of microfilaremic dogs were misdiagnosed as Filaria immitis in Pisa and in Milan [18]. In the first experiments to demonstrate the ability of mosquitoes to transmit parasites throughout their puncture, it is probable that $D$. repens larvae were used and not $D$. immitis as erroneously stated, as the adult worm was found in subcutaneous tissues [19]. Dirofilaria repens Railliet \& Henry, 1911 was first described and named in 1911 on the basis of specimens sent by Bonvicini, a clinician professor of Bologna [20]. Some years later, the L1-L3 development of the parasite in the mosquito intermediate host was elucidated [21]. As far as the clinical presentation of the infection is concerned, dermatitis by $D$. repens was reported in dogs [22-24] although no clear etiological evidence was provided.

\section{Geographical distribution of Dirofilaria repens in dogs, humans and mosquitoes}

Autochthonous $D$. repens infections have been found in dogs in most European countries, from Portugal to Russia (Fig. 1). Accordingly, human cases of dirofilariosis occur in the same areas where the infection is endemic in dogs [7] and their distribution has been previously reviewed [7, 9, 25-28]. The highest incidence of human cases has been recorded in the Mediterranean countries (Italy, southern France, Greece) and in the last two decades in some eastern European countries, namely Ukraine, Russian Federation and Belarus [7, 13, 29]. Nonetheless, many human cases are not published and the overall picture of the distribution of human dirofilariosis remains uncertain.

In the following chapters we briefly summarize and update the current distribution of $D$. repens in dogs, humans and mosquitoes in Europe, which has been divided into four zones following the Köppen-Geiger Climate Classification [30] (available at: http://koeppen-geiger.vu-wien.ac.at/pdf/kottek_et_al_2006_A4.pdf), namely Mediterranean countries (Portugal, Spain, southern France, southern Italy, and Greece), west-central and Balkan countries (northern Italy, central and northern France, UK, Belgium, Denmark, Netherlands, Germany, Switzerland, Austria, Czech Republic, Poland, Hungary, Bulgaria), eastern countries (Slovakia, Romania, Moldova, Ukraine, Belarus, Russian Federation, Lithuania, Estonia, Latvia), and Nordic countries (Norway, Sweden, Finland). Countries falling into different climatic zones have been placed in the one covering the majority of the area. Reports from other countries bordering Europe or the Mediterranean basin are also briefly mentioned.

\section{Mediterranean countries}

In Italy, the first extensive data of canine $D$. repens prevalence were obtained in the north of the country in the second half of the last century [31,32]. Interestingly, the results showed a higher prevalence of $D$. repens 


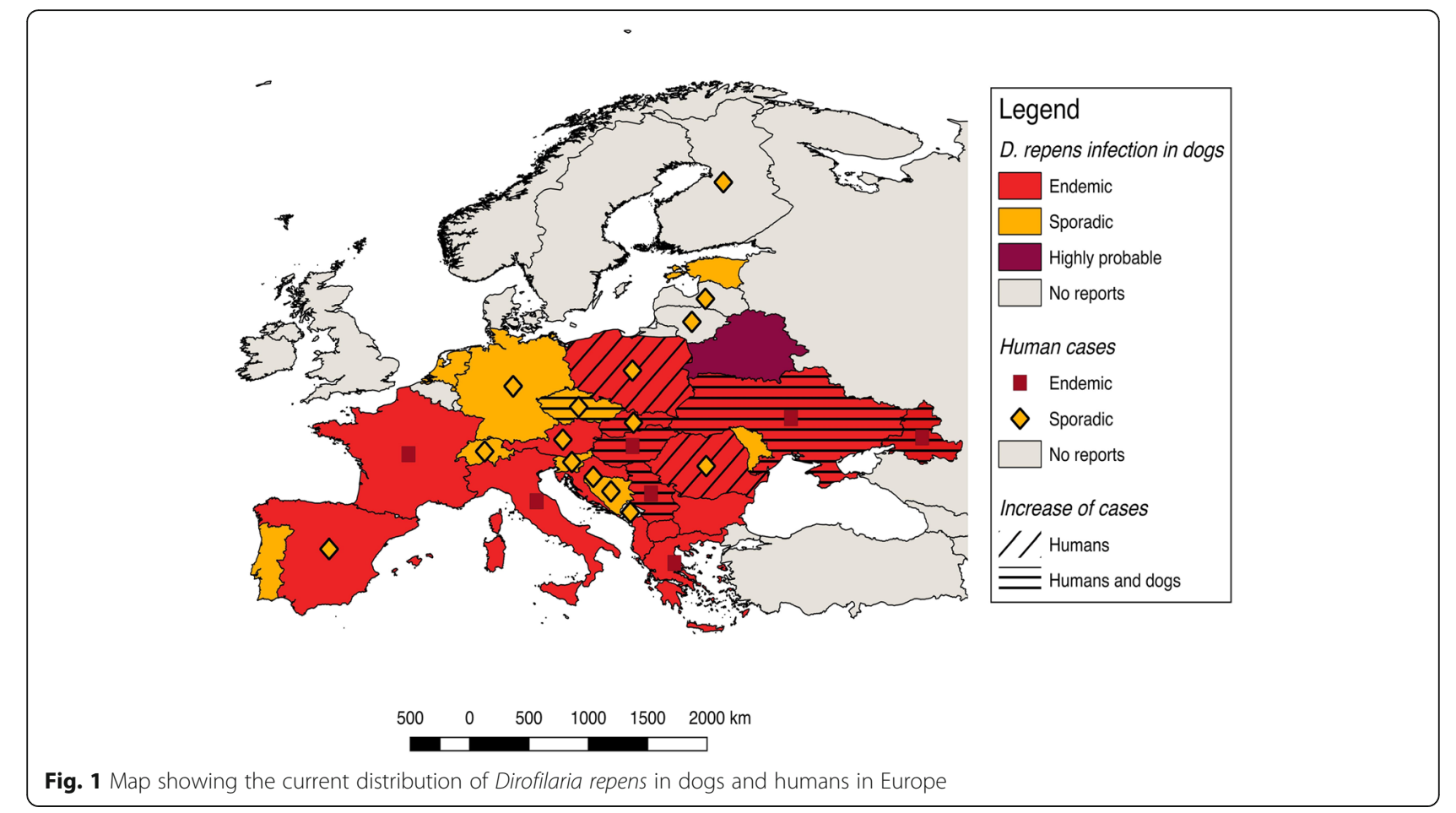

compared to D. immitis (30 vs 5\% respectively) [31, 32], while 25 years later, surveys in the same areas showed a dramatic increase of $D$. immitis in dogs (20-40\%) [33]. The most recent data indicate that $D$. repens is practically endemic in all of the peninsula and the major islands (Sicily and Sardinia) with a prevalence ranging between $1.5-12 \%$ [34-37], and that dogs are often co-infected with other filarioids, such as Acanthocheilonema reconditum and D. immitis [38-40]. Dirofilaria repens was also found in the mosquito species Culex pipiens in the northeastern part of the country [41], with an infection rate ranging between $0.23-0.71 \%$.

Accordingly, Italy is one of the countries with the most significant number of human cases $[1,8,9,42]$, and case series of up to 60 patients were published [8]. A spatial correlation has been observed, with human cases reported more frequently in areas where $D$. repens infection in dogs is highly endemic [43, 44]. For example, out of 14 cases of human ocular dirofilariosis reported in Sicily (southern Italy), eight (57.1\%) occurred in the Province of Trapani where the infection rate in dogs was as high as $20.4 \%$ [45].

Canine filariosis, caused by $D$. repens, has been documented in dogs from continental Spain and the Balearic Islands. In a study conducted in Salamanca Province (north-west Spain), blood samples from 293 dogs revealed $D$. repens in $0.3 \%$ of the animals [25]. A similar prevalence $(0.2 \%)$ was obtained after examining 1683 dogs from three areas on the Mediterranean coastline of Spain and one in the Madrid Province (central Spain)
[46]. In southeastern Spain, the presence of D. repens infection was evaluated in 114 kenneled dogs with the highest prevalence of infection (84.6\%) observed in the Alicante Province [47].

Although Spain is frequently the country of origin for human infections diagnosed in Norway, Slovenia, Netherlands and UK [48], few autochthonous human cases have been reported, namely on the island of Ibiza [49] and in the Province of Alicante [50].

In Portugal, canine or other animal cases of D. repens infection have not been reported until very recently, when the first case of canine infection was found in the Algarve, the southernmost part of the country [51]. Currently there are no reports of human infection, apart from the description of an imported case [52].

Dirofilariosis is a common parasitic disease of dogs in Greece, with a higher prevalence of $D$. repens in northern Greece (30\%) [53] compared to southern Greece $(0.68 \%)$ [54]. The infection is also expanding in the western province (Achaia), where a positive dog was recently recorded for the first time [55]. Therefore, it is not surprising that human infections in Greece have been reported since the year 2000 [56] both in residents and tourists [57].

\section{West-central and Balkan countries}

In France, $D$. repens has only recently received attention. Epidemiological studies conducted on military dogs in the southeast of France in 1986 and 1990 [58], showed a wider distribution of $D$. repens in comparison to $D$. 
immitis. A national survey on Dirofilaria infections seen in veterinary clinics conducted in 2006 [59] pointed out that at least one case of canine cutaneous dirofilariosis was diagnosed in $8.5 \%$ of the clinics. In general, the case frequency was considered relatively stable in the ten-year period 1996-2006, with a national average annual clinical prevalence calculated to be $0.005 \%$. The majority of cases (74.4\%) were considered autochthonous in the sampling area. The parasite was mainly distributed in the southern (Mediterranean), central and western (Atlantic) parts of the country [59].

A review of human cases reported in France during the period of 1923-1999 counted 75 descriptions, mainly from the southeastern part of the country [60]. Since then, another five cases have been described, including apparently new areas, resulting in a cumulative total of 80 cases until 2007. Interestingly, D. repens has been observed in 22 (23.5\%) departments of France, most of them overlapping with those where canine filariosis was previously reported [58-67]. On the island of Corsica, human cases have been reported since 1994 [68] and DNA of D. repens has been recently found in 1.5\% of Aedes albopictus mosquitoes [69].

The first empirical evidence of northern spreading of Dirofilaria infections over the Alps was in a dog from southern Switzerland at the end of the last century [70]. A few years later, another two positive dogs were found in Canton Ticino, the region bordering northern Italy [71]. Considering the close proximity of Switzerland to hotspots in Italy, it is not surprising to find some human infections in this area [72].

Other cases of possibly autochthonous D. repens infections in dogs of central Europe are reported from Germany [73-76]. However, the screening of 1023 blood samples collected in 2013 and 2014 in Brandenburg (north-eastern Germany) did not provide any evidence for autochthonous D. repens infections [77]. The finding of $D$. repens in the mosquito species Culiseta annulata, Anopheles maculipennis (sensu lato), Aedes vexans $[78,79]$ and Anopheles daciae [80], along with an analysis of weather data, suggests that active transmission within the area may occur [81]. Accordingly, in 2014 the first autochthonous human case was reported in Germany [82].

A single autochthonous case of $D$. repens infection in a dog was reported in the Netherlands in 2008 [83].

In Austria, a recent review of cases occurring from 1978 to 2014 found autochthonous D. repens infection in seven dogs [28]. The first autochthonous human case was described in 2008 [84]. The finding of the nematode in the mosquitoes An. maculipennis (s.l.) and Anopheles algeriensis [85] suggest the endemisation of the infection as well as the introduction of $D$. repens from eastern neighboring countries.
In Poland, the first foci of canine $D$. repens infection were signaled in 2009 with a high mean prevalence of $37.5 \%$ [86]. A survey conducted between 2011 and 2013 on 1588 dogs originating from all 16 provinces of Poland, revealed a nationwide distribution, with an overall prevalence of $11.7 \%$ and local values ranging from 1.2 to $25.8 \%$ [87]. A high prevalence (38\%) was recently confirmed in dogs in central Poland [88]. The first human autochthonous case was published in 2008 [89], then a retrospective survey on affected human tissues since 2007 revealed a total of 18 cases of $D$. repens infections in Poland [90].

In the Czech Republic, D. repens occurs only in lowlands in the south-east of the country, in the triangle between the rivers Dyje (= Thaya) and Morava [91, 92], with indication of recent movement northwards along the River Morava (Modrý et al., unpublished). Recently, a report on emergence of autochthonous human infections in the Czech Republic was published, geographically overlapping with known distribution of $D$. repens in dogs [93].

In Hungary, the first dog with an autochthonous $D$. repens infection was diagnosed in 1995 [94]. An epidemiological survey carried out during 2005-2006 revealed a prevalence of $14 \%$ in dogs [95]. In the following years the national prevalence of $D$. repens microfilaremic dogs was $18 \%$, with significant local variations of prevalence up to $30 \%$. [96]. Accordingly, human cases are increasingly reported and $D$. repens infection is considered an emerging zoonosis in Hungary [97-101].

Cases of $D$. repens in dogs are reported in the whole Balkan region [27], with high variations of prevalence according to the area and the type of study, such as 1447.3\% in Croatia, $11 \%$ in Albania and Kosovo, 1.9\% in Bosnia and Herzegovina and $21 \%$ in Macedonia (FYROM) [27, 102, 103].

Although prevalence surveys are not available for Slovenia, the parasite was diagnosed in a $\operatorname{dog}$ as an imported case to Germany [104].

One of the most affected countries in the Balkan area is Serbia, where $D$. repens has been found in dogs, with prevalence ranging from 17 to $49 \%$ [105]. Infection was also found to be prevalent in wild canids [106]. Dirofilaria repens has repeatedly been reported in humans [106-108] and a recent survey on canine and human cases revealed an endemic status of dirofilariosis in parts of Serbia [109].

Human cases are also reported in Croatia [110-112] and more rarely in Bosnia and Herzegovina [113], in Montenegro [107, 114] and in Slovenia [13]. The infection by $D$. repens in dogs of the Balkan countries is currently considered in expansion and human cases are correspondingly reported [110].

Studies performed in dogs in Bulgaria reported two positive (1\%) out of 192 stray dogs [115], while in Sofia 
ten years later (2005-2007), 18 (4.8\%) dogs out of 378 were found microfilaremic [116]. The analysis of data for a 39-year period found 47 cases of human dirofilariosis with various organ localizations [116].

\section{Eastern countries}

In Slovakia the first microfilaremic dogs for both Dirofilaria species were identified in 2005 during routine blood testing [117]. The first systematic research detected microfilariae of D. repens in 99/287 (34.5\%) dogs, confirming the country as a new endemic area of central Europe [118, 119].

In 2007 the first human case was also detected in Slovakia [120], two years after the first case in dogs. Since then, a total of 12 human cases have been registered at the Institute of Parasitology, Slovak Academy of Sciences [121-123]. The majority of cases came from the southern regions of the country, bordering Austria and Hungary [123]. Recently, D. repens was identified in Anopheles messeae and unidentified mosquitoes of the An. maculipennis and Cx. pipiens complexes [124].

In Romania $D$. repens was mentioned in dogs during expeditions that took place in1963-1964 [125]. In 2008, adult $D$. repens were found in a dog from the northeastern part of the country [126]. In the western counties, the prevalence of infection ranged between $2.2-7.2 \%$, close to the Hungarian border $[127,128]$. In a recent survey focused mainly on the southern parts of the country, the highest prevalence $(18.8 \%)$ was recorded in the Danube Delta (southeast), while in the southwestern counties the prevalence values ranged between 2.213.4\%, near the Danube [129].

The first human case report in Romania was published in 2009 [130], followed by a few other reports [131133]. It may be assumed that D. repens is endemic in Romania and that a considerable number of human and canine cases remain undetected.

In the former USSR, first records of $D$. repens infection in dogs originating from Ukraine and the Rostov region of Russia were reported in the first half of the 20th century [134]. More recently (2002-2009), 20.25\% of tested dogs were positive for Dirofilaria spp. microfilariae in the Rostov region, with $D$. repens single infection (44.7\%) superseding mixed infections with D. immitis (25\%) [135]. A large-scale survey conducted between 1995 and 2012 on 3258 canine blood samples revealed a prevalence of $D$. repens infection ranging between 10 $43 \%$ in southern Russia, and up to $12 \%$ and $36 \%$ in pet dogs and service dogs of northern regions, respectively [136]. Between 2000 and 2002, a similar prevalence was recorded in Kiev (Ukraine), with $30 \%$ and $22 \%$ of stray and owned dogs, respectively, being positive. More recently, similar rates (18\%) were found in client-owned dogs in Kiev [137].
In southern Russia and Ukraine, D. repens in humans is endemic and well known by local physicians [136, 138-148]. Of 264 cases of human dirofilariosis recorded in Russia between 1915 and 2001, 43\% occurred during the last three years of the period analyzed (1999-2001) [149]. According to a genetic analysis of strains isolated from patients who acquired infection in Ukraine, there are only negligible genetic differences as compared to strains from southern Europe [150]. A recent analysis of 266 cases detected in Rostov-on-Don, Russia from 2000 to 2016 reports a relatively high proportion $(10 \%)$ of mature females [151].

In various territories of Russia, infection prevalence within 6232 mosquitoes of the genera Anopheles, Aedes and Culex ranged between 1-14\% [137]. Dirofilaria repens has also been found in $1 \%$ of mosquitoes collected in Tula region, in the species Ae. vexans, Aedes geniculatus, Aedes cantans and Cx. pipiens [152].

In Moldova, few human cases were reported, but the finding of DNA of D. repens in mosquitoes from 13 of 25 trapping sites and the suitability of temperature conditions for transmission of Dirofilaria spp. within the entire country suggest an endemic status [153]. Indeed from 2010 to 2015, the highest infection rate of $D$. repens (4.91\%) was found in An. maculipennis (s.l.), whereas the most frequent mosquito species $C x$. pipiens $(s . l.) / C x$. torrentium had significantly lower infection rates $(0.88 \%)$ [153].

Thus far, the northernmost European site where the parasite life-cycle has been confirmed is Estonia (Tartu $58^{\circ} 23^{\prime} \mathrm{N}, 26^{\circ} 43^{\prime} \mathrm{E}$ ) where $D$. repens microfilariae were reported in three dogs in 2013-2014 [154], while no human cases have been suspected or confirmed.

A human case was diagnosed after surgery in 2011 in Latvia [155].

\section{Scandinavia}

In 2016, a survey of 125 veterinarians in the Baltic (Estonia, Latvia, and Lithuania) and the Nordic countries (Denmark, Finland, Iceland, Norway and Sweden) interviewed by a questionnaire on the presence of canine babesiosis, D. immitis and D. repens, suggested that autochthonous cases of the three vector-borne parasitic infections occur in the region [156]. Accordingly, an autochthonous human case has been diagnosed in Finland in 2015 [157].

\section{Other countries}

Autochthonous $D$. repens infections have been reported in both dogs and humans in Egypt [158], Tunisia [159], Israel [160, 161], Iraq [162], Saudi Arabia [163], Dubai [164], Kuwait [165], Iran [166] and Turkey [167, 168]. While D. immitis is apparently absent from some Middle Eastern countries such as Israel where $D$. repens is 
present, $D$. immitis seems to be more common in dogs than $D$. repens in other countries such as Iran and Turkey $[169,170]$.

\section{Imported human cases in central and northern Europe}

Most cases reported in central and northern Europe have been seen in travelers to endemic areas or in migrants. Most infections are acquired in southern Europe (e.g. Italy, Spain, Greece) and to a considerable extent in southern regions of Russia and Ukraine. However, infections are further imported from non-European countries, especially India and Sri Lanka. Interestingly, molecular analysis of human cases imported from India repeatedly revealed these as caused by Dirofilaria sp. "hongkongensis", which is closely related to D. repens $[171,172]$. Thus, cases from Asia, attributed to $D$. repens in the past, may indeed have been caused by Dirofilaria sp. "hongkongensis".

Additionally, human cases of $D$. repens were repeatedly diagnosed from travelers returning from Africa, including cases from countries with no previous information on the presence of $D$. repens (e.g. Senegal and Namibia; unpublished experience of the authors).

\section{Life-cycle}

Dirofilaria repens worms are parasites of subcutaneous and intramuscular connective tissues of dogs and other carnivores (e.g. foxes, wolves and coyotes) (Fig. 2). The females of $D$. repens are viviparous and after mating, microfilariae are released in the peripheral blood and are picked up by a mosquito, the intermediate host, during the blood meal. Soon after ingestion, microfilariae migrate from the midgut to the Malpighian tubules through the haemocoel of the insect, where they molt into the second (L2) and third (L3) infective larval stages (Fig. 3). The L3 then actively leave the Malpighian tubules to migrate through the body cavity and the thorax

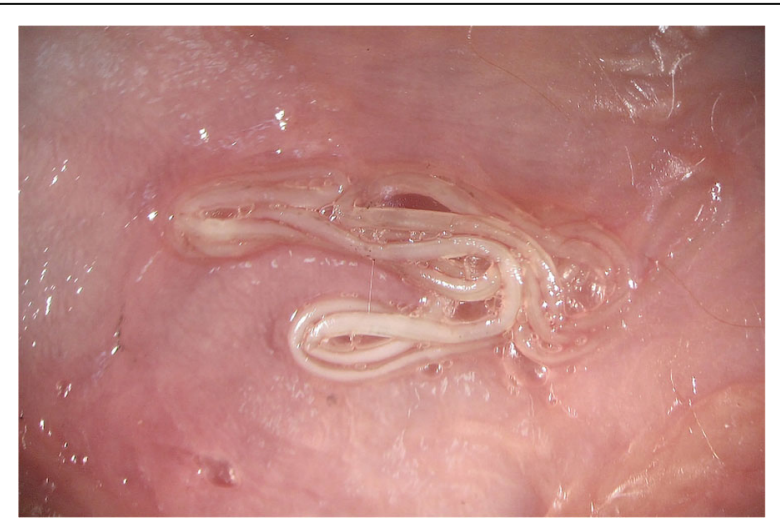

Fig. 2 Adult specimen of Dirofilaria repens detected in the subcutaneous tissue of a dog during a necropsy (courtesy of Riccardo Paolo Lia) to the head and finally the proboscis where they wait until they are transmitted to the next host. The developmental process is temperature-dependent and takes about $8-13$ days at $27-30{ }^{\circ} \mathrm{C}, 10-12$ days at $24-26{ }^{\circ} \mathrm{C}$ and $16-20$ days at $22{ }^{\circ} \mathrm{C}$ [173-175]. A delay of four days has been observed in the development at $22.5{ }^{\circ} \mathrm{C}$ and $29.4 \%$ relative humidity (RH) in comparison to $24.5{ }^{\circ} \mathrm{C}$ and $80.9 \% \mathrm{RH}[174,176]$. At $18{ }^{\circ} \mathrm{C}$, the development needs 28 days $[173,175,177]$. In the mammalian host, the L3 migrate to the subcutaneous tissue and undergo two additional molts (from L3 to L4 and to preadult worms), finally maturing into adults. In dogs, the prepatent period is 189-239 days [175], although in a recent study the first microfilariae were found in the bloodstream on day 164 post-infection (pi) [178]. Dirofilaria repens nematodes may live up to ten years (on average two to four years) and females potentially produce microfilariae throughout their lifespan [4].

\section{Epidemiology \\ Vectors and transmission}

In Europe, the known vectors of $D$. repens are mosquito species of the genera Anopheles, Aedes, Culex and Coquillettidia, with Culex pipiens pipiens [28, 41, 177, 179, 180] and Aedes albopictus implicated as the main vectors in southern Europe $[177,179,181]$. In central Europe, $A e$. vexans and mosquitoes of the $C x$. pipiens complex may readily act as potential vectors [41, 182-184].

Other mosquito species indigenous to Europe are indicated as possible vectors in nature: An. algeriensis [185], An. daciae [186], An. maculipennis (s.l.) [79, 182, 185], Ae. caspius [179] and Cs. annulata [79]. Recent studies conducted in highly endemic areas in southern Hungary and northeastern Italy have shown that the molecular screening of blood-fed or host-seeking mosquitoes is an adequate tool to verify the presence of $D$. repens and other mosquito-transmitted filarioid helminths in a certain area [41, 182]. However, the simple detection of filarial DNA is not enough to confirm the occurrence of microfilariae development into infective L3 stages. Filarial DNA must be detected in separate body regions of the mosquito and the positivity of the head/thorax samples can indicate that infective larval stages had developed within the mosquito host $[177,180,181]$.

\section{Vector competence}

Several factors define the vectorial capacity of a mosquito species for a specific pathogen: vector competence (i.e. the percentage of vector individuals able to support the development to the infective stage), mosquito density and seasonality, extrinsic incubation time, host preference and daily biting rate, expected infective lifetime, the mosquito daily survival rate, as well as the availability and density of infected vertebrate hosts [80, 81, 187]. 


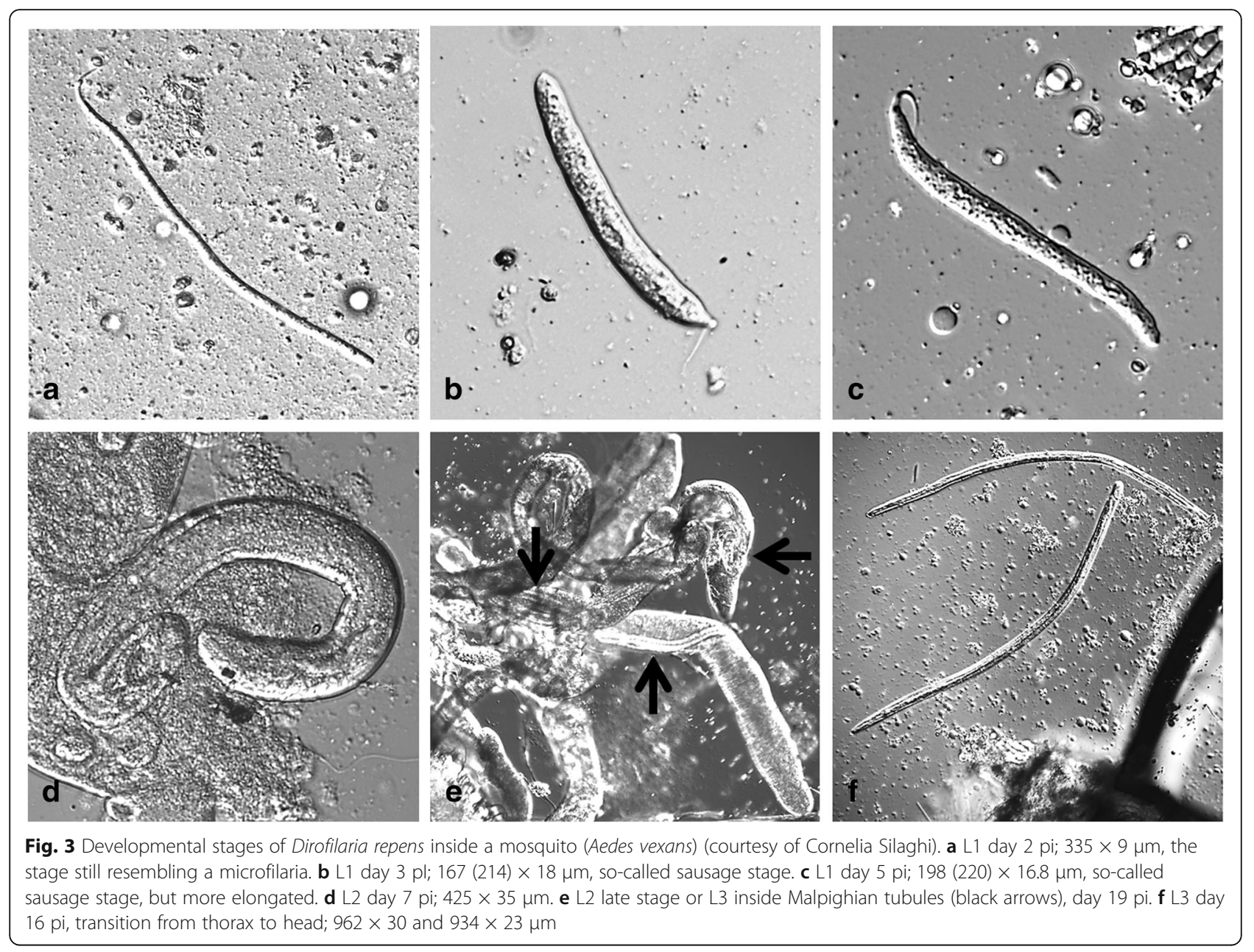

For the successful transmission of $D$. repens $\mathrm{L} 3$ to a canine (or other vertebrate) host, an infected mosquito must survive for at least the extrinsic incubation time until the highly motile L3 have reached the proboscis. Furthermore, the mosquito species needs to be endemic at localities where dogs are present to acquire and transmit the infection, and it needs to have a particular biting preference for canines. Therefore, this renders mosquito species with a mammalian host preference present in urban and suburban localities suitable for the support of an endemic $D$. repens cycle.

The vector competence of several mosquito species for $D$. repens has been shown in experimental laboratory studies by observation of the development to the infective L3 stage: Ae. aegypti [15, 174, 176, 188]; Ae. albopictus [189]; Ae. caspius, Aedes detritus [173]; Aedes mariae [174]; Ae. vexans, Anopheles stephensi [175]; Anopheles claviger; An. atroparvus [175]; Anopheles sinensis [174]; Culex pipiens molestus [188]; Aedes togoi [190]; Ae. geniculatus; and Aedes japonicus [191]. Different methods for the infection of the mosquitoes were applied in these studies such as the direct feeding on a microfilaraemic animal $[173,176,188]$ or the artificial membrane feeding with infected blood [192].

Furthermore, within a certain species of mosquitoes, susceptibility or refractoriness may vary considerably and may be dependent on certain genes, as has been shown for Ae aegypti [193]. Controversial results exist also for Cx. pipiens, as it has been shown both susceptible and refractory in laboratory experiments [176]. This might be attributed to testing of different biotypes (pipiens, molestus and their hybrids) that possess different vectorial capacity. Culex pipiens fatigans, Anopheles gambiae complex, Aedes vittatus, Ae. aegypti and Mansonia africana were also shown to be refractory to $D$. repens infection in laboratory investigations $[176,191]$. All microfilariae in the latter mosquito species were trapped inside the midgut in the blood clot and were disintegrated and no longer observable after day 5 pi. This retention of microfilariae has been described as potentially beneficial to the vector-parasite interaction system. A reduced microfilarial burden can lead to increased mosquito longevity, potentially making it more efficient transmitting host [194]. Microfilaria burden can 
vary greatly in a canine host and consequently also the uptake of microfilariae by a mosquito vector. This variation may be due to the circadian rhythms of microfilariae in the peripheral blood and mosquito vector biting $[6,175]$.

Apart from the process of microfilaria degradation and melanisation as part of an innate immune response of the mosquito host [195], it was also assumed that the anatomical structures of the alimentary channel and the physiology of the respective mosquito species influence the development of microfilariae, for example the speed of blood clotting after blood intake (discussed in [188]). Some authors have highlighted the importance of mosquito cibarial armature and peritrophic membrane in the transmission of $D$. repens. Indeed, cibarial armature and dome can mechanically damage a high proportion of microfilariae, which are ingested with the blood meal, and possibly serve to protect mosquitoes [188, 189]. Development and complexity of the cibarial armature differ between different species. In some it is absent (An. atroparvus, An. claviger, Ae aegypti and Ae. mariae), in others it has one (Anopheles albimanus and Anopheles farauti) or two (An. gambiae, Anopheles stephensi and Anopheles superpictus) rows of cibarial teeth, whereas in $C x . p$. pipiens teeth of cibarial armature are spoon-shaped and the cibarial dome is strongly denticulated $[196,197]$. The number of damaged erythrocytes varied between $2-4 \%$ in the first, and $45-50 \%$ in the last group. The time needed for formation of peritrophic membranes in adult mosquito varies between 4 and $12 \mathrm{~h}$ in different species [198].

\section{Risk factors}

No study has been published on risk factor analyses using a multivariate approach, which would be more suitable for highlighting confounding factors and biases. Therefore, some of the associations found and often reported as risk factors (Table 1) are likely the results of the interaction of different factors related to the host (sex, age, breed and lifestyle), the vector (presence, density, vectorial capacity and attraction to dogs), the environment (rural, urban, climate) and the human intervention (use of specific chemoprophylaxis and/or physical or chemical protection against mosquitoes).

The evaluation of the frequency of the factors associated with $D$. repens prevalence in literature, in particular male and guard dogs, older age and outdoor lifestyle, suggests that the higher exposure to mosquito bites is the only risk factor clearly associated with $D$. repens prevalence.

\section{Canine subcutaneous dirofilariosis}

Although canine $D$. repens infections very often runs asymptomatically, a plethora of nonspecific dermal
Table 1 Factors significantly associated with Dirofilaria repens prevalence in dogs of Europe

\begin{tabular}{|c|c|c|c|}
\hline No. of dogs tested & Country & Potential risk factors & Reference \\
\hline \multirow[t]{2}{*}{114} & \multirow[t]{2}{*}{ Southern Spain } & $\begin{array}{l}\text { Kenneled dogs (lack of } \\
\text { preventative measures) }\end{array}$ & \multirow[t]{2}{*}[47]{} \\
\hline & & Geographical location & \\
\hline \multirow[t]{4}{*}{2406} & \multirow[t]{4}{*}{ Central Italy } & Older age & \multirow[t]{4}{*}[294]{} \\
\hline & & Male sex & \\
\hline & & Pure breed & \\
\hline & & Traveling dogs & \\
\hline \multirow[t]{3}{*}{151} & \multirow[t]{3}{*}{ Eastern Slovakia } & Older age & \multirow[t]{3}{*}{ [119] } \\
\hline & & Lifestyle (outdoors) & \\
\hline & & Geographical location & \\
\hline \multirow[t]{2}{*}{972} & \multirow[t]{2}{*}{ Central Italy } & Rural environment & \multirow[t]{2}{*}[34]{} \\
\hline & & Geographical location & \\
\hline \multirow[t]{2}{*}{194} & \multirow[t]{2}{*}{ Northern Serbia } & Older age & \multirow[t]{2}{*}[295]{} \\
\hline & & Geographical location & \\
\hline \multirow[t]{2}{*}{2512} & \multirow[t]{2}{*}{ Southern Italy } & Lifestyle (guard dogs) & \multirow[t]{2}{*}{ [296] } \\
\hline & & Geographical location & \\
\hline
\end{tabular}

alterations has been reported such as skin nodules, pruritus, thinning, itching and asthenia [10, 59, 199, 200]. Usually, no inflammatory reaction or connective capsules are surrounding the living parasite (Fig. 2a), which can be seen moving actively under the connective serous layers [4]. Non-inflammatory subcutaneous nodules, cold, not painful and mobile, can be seen on the skin surface of infected animals. Inflammatory and painful nodules may be associated with localizations such as the scrotum. Granulomatous capsules generally surround dying and degenerating worms. These clinical alterations, however, must be supported by histopathological data or $D$. repens microfilaria-positive blood examinations or molecular identification from biopsy. Lesions may also appear as circular alopecic areas with lichenification, hyperpigmentation and erythematous and scaling margins [201] and they can occur in the lumbosacral and perianal regions [164]. Skin affections may be pruritic or not, suggesting that itching is not crucial for a presumptive diagnosis of $D$. repens-associated dermatitis. An unusual case of allergic non-pruritic diffused dermatitis caused by $D$. repens, confirmed by histological examination, has also been described [201].

Dirofilaria repens infection was the aetiological cause of ocular lesions in a dog reporting conjunctivitis and later additional ocular and nasal mucopurulent discharge [202]. Worms were then found in a dorsonasal bulbar conjunctival mass and in the ventral palpebral conjunctival fornix and confirmed as $D$. repens by PCR. Rarely, D. repens may reach ectopic body parts. A case of adults in the pelvic cavity and mesentery 
was reported in a dog with a diagnosis of kidney failure and chronical cystitis [203].

The histological examination of lesions may reveal the presence of multifocal purulent dermatitis, panniculitis, hyper-pigmentation and hyperkeratosis [10]. Generalized cardio-hepato-renal insufficiency may also occur [87]. Pathological changes are most likely associated with the presence of adult nematodes or microfilariae [10]; however, symbiotic Wolbachia bacteria, which live in the hypodermal chords of Dirofilaria male and female adults, and in the female germline [204], have been shown to increase the level of pro-inflammatory cytokine (e.g. IL-8) and induce chemoattraction [205, 206].

\section{Human infections}

Humans acquire the infection in the same manner as dogs, by the bite of a mosquito, but it is probable that most of the infective larvae die shortly after, with the infection resolving unrecognized and without causing any specific symptom [1, 8]. No predisposing factors are known to explain why in some cases larvae may develop further. After the bite of an infective mosquito, a stronger reaction with erythema, swelling and pruritus lasting $5-8$ days is reported $[1,8]$. In most of the cases a single worm develops, probably because the stimulation of the immune system prevents the development of others [1, 8]. In rare cases the worm may develop to a mature adult $[1,207,208]$ and even fertilized worms releasing microfilariae have been described, especially in immunosuppressed patients $[1,8,42,146,209-212]$, which in very rare cases may even reach the bloodstream [213].

In infected patients, the developing stages of $D$. repens migrate subcutaneously $[1,8,61]$ for weeks up to several months in several parts of the body, usually with mild and unrecognized symptoms $[1,8,61]$ and only sometimes causing larva migrans-like symptoms (i.e. irritation and itching) $[1,8,42,61,131,211,214]$. In one case, a patient, after scratching a pruritic lesion, removed a 6 $\mathrm{cm}$ long whitish worm from the wound [215]. During migration $D$. repens may reach the eyes $[1,8,61,211]$, becoming visible through the subconjunctiva $[1,5,72$, 110, 113, 168, 214, 216-219] (Fig. 4). Larval stages localized in the eyes can be removed surgically without serious damage $[1,214,219]$. However, in rare cases, serious sequelae (glaucoma, uveitis, episcleritis and retina-detachment) may develop and ultimately lead to significant loss of vision $[1,8,100,147,220-222]$.

After weeks to several months from the infection, $D$. repens may stop to migrate and form a nodule of about one centimeter $[1,8]$. In most cases, the nodules develop subcutaneously $[1,8,48,63,93,108,111,116,138,158$, 212, 223-228]. Nodules have been reported in various human body areas and tissues, mostly in the superficial tissues of the facial regions $[1,8]$, as perioral and

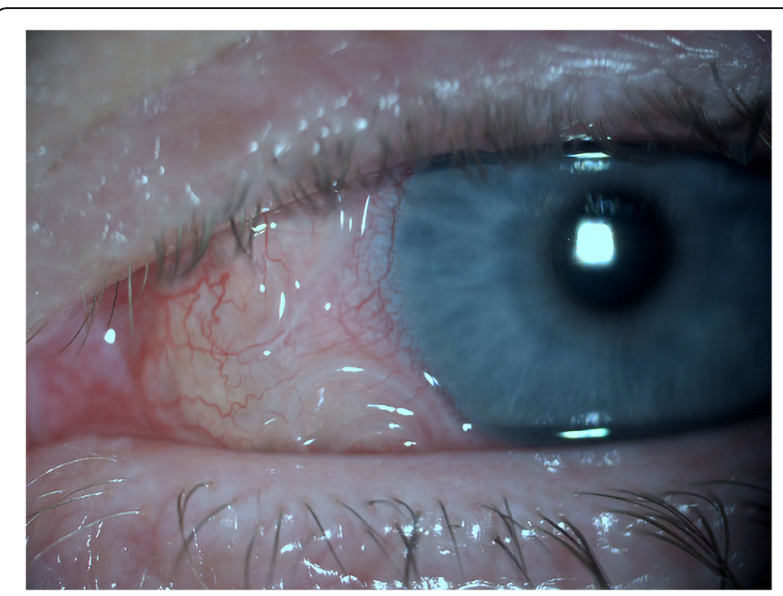

Fig. 4 Dirofilaria repens visible in the subconjunctiva of a human eye (courtesy of Ramin Khoramnia and Aharon Wegner)

periorbital tissues [107, 167, 224, 226, 227, 229-234], forehead [235], skin of the lower leg [93], soft tissues of the hand [236] or finger [93], subcutaneous tissue of the hypogastrium [93] and of the neck [237]. Other predilection sites are scrotum and testicles and, to a lesser extent, the breasts of women $[1,8,65,223,235,238-245]$. Various reasons have been hypothesized for these preferences, such as lower body temperature of these areas, higher awareness of patients for these body parts or a tropism of $D$. repens to higher concentrations of sexual hormones [1].

The nematodes may also reach deeper body areas, such as lymph nodes [93], the abdominal cavity [93, 99], lungs $[1,56,158,246]$, muscles [247] and even the dura [64].

If left untreated, $D$. repens may survive for up to one and a half years $[1,8]$. The symptoms caused by $D$. repens nodules depend on their localization, usually being limited to a local irritation, erythema and pruritus $[1,8,93]$. Rarely, a strong local immune reaction develops, and the nodules may appear like a suppurating abscess with local infection accompanied by a mild systemic reaction, including elevation of body temperature and mild eosinophilia $[1,8,206]$. In very rare cases, even more severe systemic immunoreactions may develop, manifesting as fever or lymphadenopathy. A case of meningoencephalitis has also been reported [211]. Comparatively severe symptoms are seen in immunosuppressed patients and in the rare cases where microfilariae develop $[1,8]$.

\section{Diagnosis in dogs}

Diagnosis of $D$. repens may be performed by detection and identification of circulating microfilariae, morphological and molecular identification of adult parasites, cytological examination of fine-needle aspiration biopsies and histopathological examination of excised nodules. In the case of localized skin lesions, the adult 
nematodes can be recovered from the nodules located in different anatomical sites of the animal (e.g. chest or lower limbs) [10] (Fig. 5), while in cases of localized or generalized dermatitis adults are almost impossible to find.

On gross examination, the cuticle of $D$. repens specimens is whitish, with distinct longitudinal ridges on the surface (Figs. 6 and 7), and narrows at the ends. Males measure $48-70 \mathrm{~mm}$ in length and $3.7-4.5 \mathrm{~mm}$ in width, while the females are larger, reaching $100-170 \mathrm{~mm}$ in length and of 4.6-6.5 mm in width [248, 249]. Upon accurate microscopic observations, the clarification of specimens with lactophenol or with glycerine for temporary mounts, allows the observation of distinct morphological features, such as the vagina in the female, which opens at 1.1-1.9 mm from the oral aperture, or the two spicules in the male, measuring 430-590 and $175-210 \mu \mathrm{m}$, respectively, as well as $4-6$ precloacal papillae (1-2 post-anal and 3 caudal). In the case of adults embedded in the nodule, $D$. repens specimens are identified at the histology on the basis on their body diameter $(220-600 \mu \mathrm{m})$, and by the presence of the longitudinal ridges, each separated from the others by a distance that is larger than the width of the actual ridge itself [250]. In transverse sections stained with haematoxylin-eosin, the occurrence of longitudinal muscles and the multilayered cuticle, expanding in the region of the two large lateral chords, is indicative for $D$. repens $[10,250]$.

The subcutaneous nodules can be also examined by ultrasound and the parasite is visualized as double linear parallel hyperechoic structures [251].

More often the diagnosis of subcutaneous dirofilariosis is based on the visualization (see Additional file 1) and morphological identification of the blood-circulating microfilariae, by concentration methods (e.g. modified Knott's test or filtration) (Fig. 8), histochemical staining (e.g. acid phosphatase activity) and fine needle sampling of nodules containing fertile adults. A blood sample

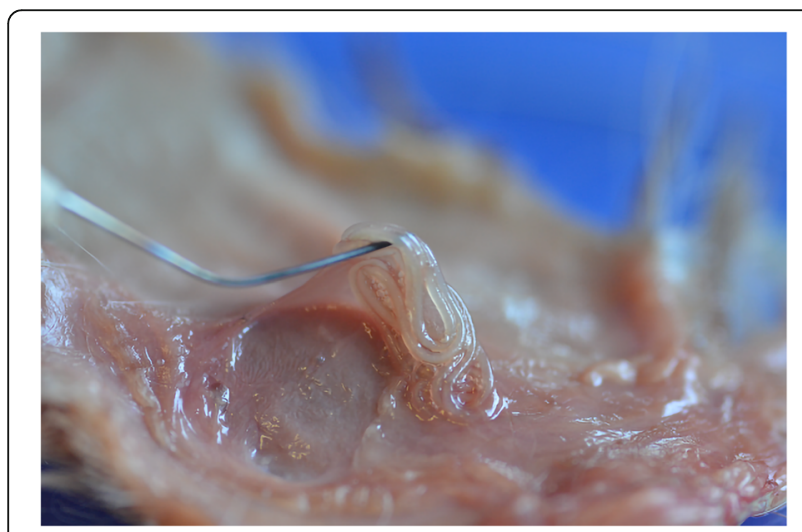

Fig. 5 Adult Dirofilaria repens removed from the subcutaneous tissue of a dog during necropsy (courtesy of Riccardo Paolo Lia)

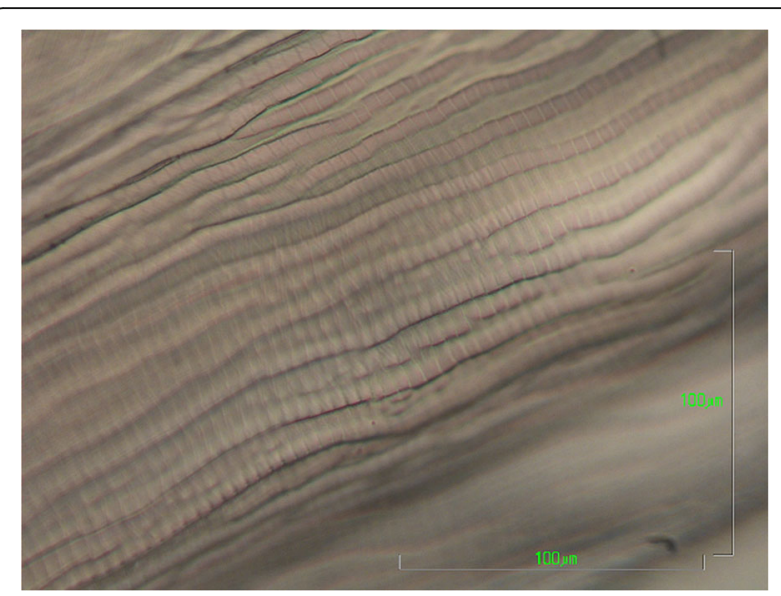

Fig. 6 Aspect of the ridges of the cuticle of Dirofilaria repens under scanning electron microscopy (courtesy of Sven Poppert). Scale-bars: $100 \mu \mathrm{m}$

taken in the evening may maximize the chance to find circulating microfilariae, due to the circadian variation of microfilariae in naturally infected dogs [6,252].

Dirofilaria repens microfilariae are unsheathed, having an obtuse-rounded cephalic margin (Fig. 5), and a long sharp tail, often curved [253, 254]. Their size may vary as a consequence of collection and fixation methods. The mean length is $300-370 \mu \mathrm{m}$ and the mean width is $6-8$ $\mu \mathrm{m}$ [253]. In a recent study [254], a mean length of 369.44 $\pm 10.76 \mu \mathrm{m}$ and a mean width of $8.87 \pm 0.58 \mu \mathrm{m}$ was reported using the Knott's test on 171 microfilaraemic dog blood samples originating from eight European countries. The test was able to clearly distinguish between $D$. immitis, D. repens and Acanthocheilonema spp. [254].

On the contrary to $D$. immitis infection, for which several, easy and rapid in-clinic test kits, based on

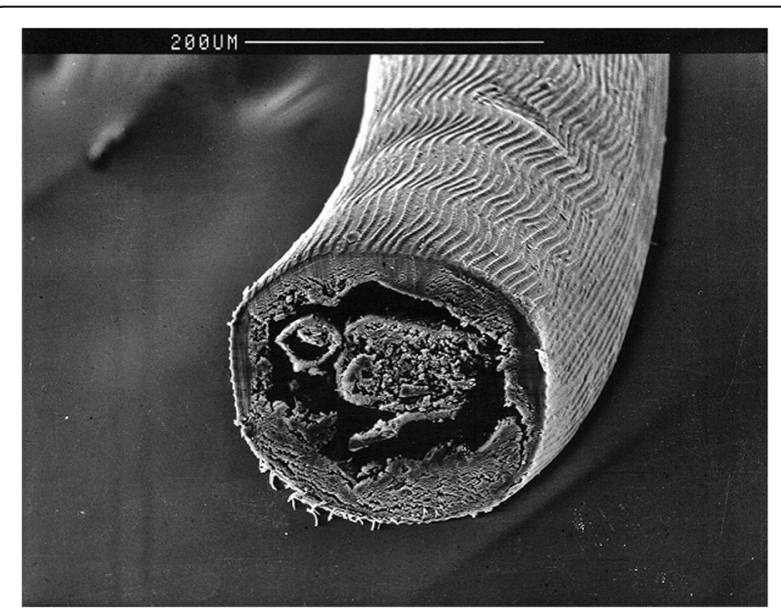

Fig. 7 Cuticle morphology of Dirofilaria repens under scanning electron microscopy (courtesy of Salvatore Giannetto). Scale-bar: $200 \mu \mathrm{m}$ 


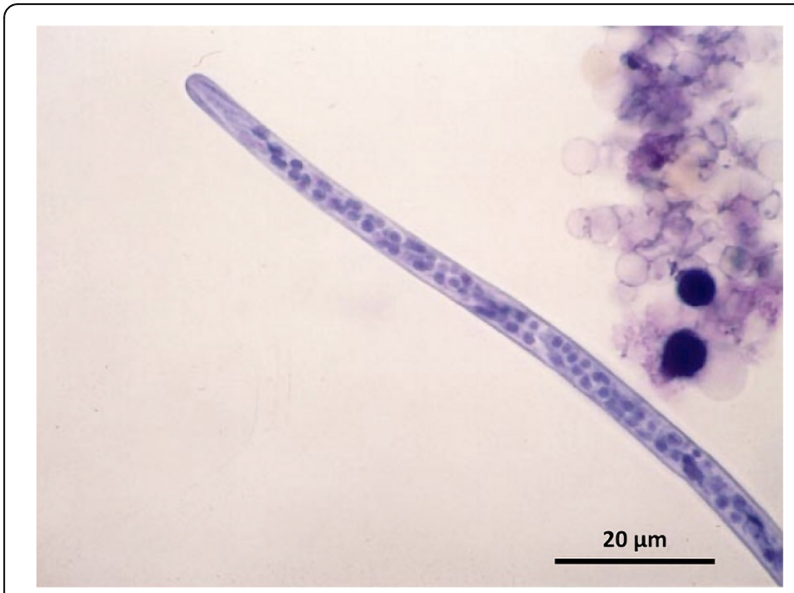

Fig. 8 The round head of the microfilaria of Dirofilaria repens (Knott's test). Scale-bar: $20 \mu \mathrm{m}$

detections of circulating antigens mainly produced by females, are commercially available for the serological diagnosis of the infection, no similar specific serological tests are available for $D$. repens.

The identification of $D$. repens may be carried out by molecular methods testing parts of adult specimens, microfilariae (in whole blood or on filter paper), or larval stages in the mosquito vectors. Various techniques have been developed for the specific detection of $D$. repens, such as multiplex PCRs targeting several filarioid species, but also for the entire superfamily Filarioidea. Amongst these are conventional and real-time PCRs, probe-based or high-resolution melting analysis techniques. The most common gene targets used are the cytochrome $c$ oxidase subunit $1(\operatorname{cox} 1)$ as a barcoding gene, the inter-genic spacer (ITS) regions, and $12 S$ rRNA gene [41, 184, 185, 255-259]. Other target genes used to identify the nematode are listed in Table 2 . The high sensitivity of real-time PCR allows the detection of small amounts of genomic DNA either in dog blood or

Table 2 Target genes used to identify Dirofilaria repens in animals, humans and mosquitoes, available on GenBank (accessed 10th September 2018)

\begin{tabular}{lll}
\hline Gene & Hosts & Length (bp) \\
\hline 12S rDNA & Human, dog, cat, mosquito & $116-510$ \\
cox1 & $\begin{array}{l}\text { Human, dog, cat, mosquito, } \\
\text { beech marten }\end{array}$ & $123-715$ \\
16S rDNA & Human, mosquito & $366-487$ \\
18S-5.8S-28S rDNA & Human, dog, mosquito & $153-2230$ \\
18S-small subunit & Human, dog, jackal & $613-839$ \\
ribosomal RNA & & \\
hsp70 & Dog & 553 \\
rbpl & Dog & 594 \\
MyoHC & Dog & 734 \\
\hline
\end{tabular}

mosquitoes (2.5 and $0.3 \mathrm{pg} / \mu \mathrm{l}$ for $D$. immitis and $D$. repens, respectively) being potentially useful for epidemiological studies [41]. In addition, a multiplex PCR targeting a barcoding region within the $\operatorname{cox} 1$ gene was developed for the simultaneous detection of almost all the filarioids infecting dogs in Europe (i.e. D. immitis, $D$. repens, A. reconditum and Cercopithifilaria sp.) [260], therefore representing a new tool for the molecular detection and differentiation of canine filarioids in blood and skin samples. Nonetheless, positive PCR alone should not be considered sufficient to establish $D$. repens as a cause of subcutaneous nodular lesions in the absence of clear cytological picture [261].

\section{Diagnosis in humans}

The diagnosis of a $D$. repens infection in humans is affected by the localization of the worm and the clinical symptoms. If the infection occurs as larva migrans, especially in the subconjunctiva, and the patient was not exposed to other potential causes of larva migrans, the clinical picture is highly suggestive of $D$. repens. The anamnesis should exclude the visit of the patient to endemic areas of other filarioids, such as Loa loa in Africa. In case of intraocular cysts or subcutaneous nodules, the diagnosis is more difficult, but a live moving worm can be seen using a pre-operative high-resolution ultrasound [231, 245].

In most cases, the definitive diagnosis is obtained after the worm removal, using the same methods applied for animals. Microscopically, D. repens females do not usually contain microfilariae. The most discriminative features of $D$. repens are the longitudinal ridges of the cuticle (Figs. 6 and 7), not present in any other filarial worm infecting humans except for Dirofilaria sp. "hongkongensis", a recently proposed new species from Hong Kong [262] and Dirofilaria ursi present in North America, North Europe and Japan in bears and rarely also in humans [171].

Since none of the described features are entirely specific, molecular tools should be applied in order to confirm the morphological diagnosis and avoid misdiagnosis, which may occur in some case with $D$. immitis [263]. In this respect, it should be suggested to surgeons to conserve the removed worm, one part in formalin for histology and another refrigerated or frozen for molecular identification. Most typical features are recognizable in histological slides, if a proper section is available and the worm not degraded. In these cases, it is still possible to perform molecular investigations from paraffin sections. An extensive description of $D$. repens in human tissue is already available [264].

Serological investigations are not helpful in human cases. In filarial infections, the immunological reaction is mainly triggered by microfilariae, which rarely develop in humans. Therefore, in most human $D$. repens cases, no 
antibodies against filariae are detectable or very low titers can be found [47]. However, such low titers are also seen in other nematode infections due to cross-reactive antibodies. The investigation of blood samples by microscopy or PCR is not useful for the same reason.

\section{Mitochondrial genotypes and potential cryptic species}

A new species of Dirofilaria infecting dogs and humans has been first described from Hong Kong and designated as Dirofilaria sp. "hongkongensis" [262, 265]. This new species was proposed on the basis of relative short DNA sequences from the mitochondrial cytochrome $c$ oxidase 1 and the nuclear ITS1 locus. Unfortunately, at that time all ITS1 sequences on GenBank were from D. repens samples collected from Thailand while all ITS2 sequences were of European origin which hampered comparisons with European $D$. repens data. Complete sequencing of mitochondrial genomes from four worms initially identified as $D$. repens using morphological features and short DNA sequences, revealed that three sequences from European samples were very similar while a fourth one collected from a patient after traveling in India was very similar to Dirofilaria sp. "hongkongensis" [171]. An additional $D$. repens mitochondrial genome sequence available from GenBank (accession no. KR071802) is also highly similar to the other European samples but its geographical origin is not available from the database entry. The organization of these mitochondrial genomes is identical to those of other onchocercids and like all clade III nematode mitochondrial genomes lacks the atp- 8 gene that is present in most animal mitochondrial genomes. It is slightly smaller than any of the other mitochondrial genomes described for the Onchocercidae and has the most extreme AT skew with a very high $\mathrm{T}$ content on the coding strand.

Phylogenetic analysis using all coding regions from the whole genomes revealed that D. repens and Dirofilaria sp. "hongkongensis" are more closely related to each other than to D. immitis [171]. However, as long as no other mitochondrial genomes from species of the subgenus Nochtiella are available, it remains speculation how closely related both species actually are. The overall similarity of mitochondrial genomes was lower than for the comparison between the human parasite Onchocerca volvulus and its sibling species Onchocerca ochengi infecting cattle. This suggests that both might represent valid species [171]. Sequencing of partial genomic fragments of approximately $2.55 \mathrm{~kb}$, including the most variable long non-coding region of the mitochondrial genome, from 41 canine samples (29 from Europe and two from Thailand) and one human sample from Vietnam, revealed further heterogeneity. In the phylogram, all European and the Vietnamese sequences were located in the same statistically highly supported cluster with the complete $D$. repens mitochondrial genome sequences. With the exception of only two samples (one from Hungary and one from Poland), differences between the remaining $D$. repens sequences were small although there were some subclusters containing preferentially samples from Poland and Hungary or from southwestern Europe and Hungary in addition to a German sample. The two samples from Thailand had very similar sequences and were more similar to Dirofilaria sp. "hongkongensis" than to the D. repens cluster. However, the genetic distance between samples from India and Thailand was considerable and the latter might represent a third species [171]. These data support the view that what is currently considered to be $D$. repens is in fact a species complex with different genotypes. However, data are not sufficient yet to decide whether different genotypes from various geographical origins represent valid species, subspecies with limited geographical range or only variants within a population. Multi-locus phylogenetic analyses using samples from diverse endemic regions combined with experimental crosses would be required to define valid genospecies within the $D$. repens complex.

\section{Treatment and prevention \\ Dogs}

Due to the lack of specific clinical alterations, the treatment of $D$. repens infection in dogs often goes along with its prevention, which should be routinely performed in order to reduce the risk for the transmission to humans (Table 3). Most therapeutic protocols currently available have been translated from the experience developed in the prevention of heartworm disease and are based on the administration of macrocyclic lactones. However, contrary to heartworm disease, very few experimental studies have been carried out to assess the efficacy of macrocyclic lactones against D. repens [4].

A complete clearance of $D$. repens microfilariae was achieved in a dog treated with an off-label protocol based on melarsomine injection followed by doramectin [160], but this fact needs further confirmation since no

\begin{tabular}{|c|c|c|}
\hline Active ingredient & Formulation & Dosage \\
\hline Ivermectin & Tablet/Chewable & $6 \mu \mathrm{g} / \mathrm{kg}$ \\
\hline Ivermectin + Praziquantel & Chewable & $6 \mu \mathrm{g} / \mathrm{kg}+5 \mathrm{mg} / \mathrm{kg}$ \\
\hline Ivermectn + Doxycycline & Chewable + Tablet & $6 \mu \mathrm{g} / \mathrm{kg}+10 \mathrm{mg} / \mathrm{kg}$ \\
\hline Doramectin & Injectable & $0.4 \mathrm{mg} / \mathrm{kg}$ \\
\hline $\begin{array}{l}\text { Milbemycin oxime + } \\
\text { Praziquantel }\end{array}$ & Chewable & $0.5-5 \mathrm{mg} / \mathrm{kg}$ \\
\hline Moxidectin & Injectable & $0.17 \mathrm{mg} / \mathrm{kg}$ \\
\hline Moxidectin + Imidacloprid & Spot-on & $2.5-10 \mathrm{mg} / \mathrm{kg}$ \\
\hline Selamectin & Spot-on & $6 \mathrm{mg} / \mathrm{kg}$ \\
\hline
\end{tabular}


efficacy was found in previous clinical studies [4]. Different dosages of moxidectin in oral, injectable sustainedrelease and spot-on formulations showed long-term suppression of $D$. repens microfilaraemia, being highly efficacious for the treatment of dogs positive for subcutaneous dirofilariosis in both natural conditions and experimental studies [266-271]. Currently, the only protocol claiming adulticidal activity for this filarioid is represented by the use of a spot-on product containing imidacloprid/moxidectin for six consecutive months, a protocol which has also been used to prevent the onset of skin lesions and dermatitis caused by the parasite [178]. Interestingly, the microfilaricidal efficacy of monthly administration of ivermectin [272] may be improved by including doxycycline [273]. This therapeutic schedule represents a novel approach for the treatment of dirofilariosis, targeting the Wolbachia endosymbionts of the nematode [274] and allows the reduction of the recommended ivermectin dosage, along with a minor risk of drug resistance.

As in the case of the treatment, the prevention of $D$. repens infection is largely based on the regular use of macrocyclic lactones (Table 3). When designing a rational approach for the control of dirofilariosis, the regional distribution patterns and the transmission period of the parasite should be taken into account, which derives from detailed epidemiological maps of the disease.

The prevention of $D$. repens transmission becomes increasingly important, considering that reducing the burden of canine dirofilariosis represents the only effective measure to decrease the risk for human infection, as dogs are the most important reservoir of the parasite.

Monthly applications of selamectin in a spot-on formulation were successfully used to reduce the pathogen transmission under natural field conditions for six months [275]. In addition, when infected animals were treated twice a month, the period of dog protection increased to nine months [276]. The use of moxidectin in a sustained-release formulation administered subcutaneously was found to have a complete efficacy in the prevention of $D$. repens in an experimental trial [269] and the authors suggested that the excellent action of the formulation was most likely attributed to the high lipophily of this active ingredient, which is stored in the body fat. Furthermore, moxidectin may be of great value towards the prevention of this filarial parasite and against adult parasites, when given as a spot-on treatment in combination with imidacloprid (imidacloprid $10 \%$ and moxidectin $2.5 \%$ ) [40, 178].

Finally, milbemycin oxime, another macrocyclic lactone, given orally once per month also proved to be effective in protecting dogs from subcutaneous dirofilariosis in endemic areas and may offer further chemoprevention option [277].
Another important part of the prevention of infection is based on contact repellent insecticides. This can be obtained by the use of veterinary products that contain pyrethroids with a specific label on the prevention of Culex and/or Aedes bites. This prevention is particularly important in periods of activity of mosquitoes and in areas where the risk of transmission is high. The use of topic repellent may also decrease the transmission of Dirofilaria from infected dogs to mosquitoes [278].

\section{Humans}

Theoretically, no special treatment is necessary in humans, because $D$. repens does not cause severe symptoms and usually dies after some time $[1,8]$. The nematode can be removed by surgery, a practice that is also needed for the etiological diagnosis and to exclude other severe diseases, such as a carcinoma $[1,8]$. As soon as $D$. repens has formed a stationary nodule, surgical removal can be conducted following standard procedures corresponding to the site of infection.

If a migrating $D$. repens is discovered in the conjunctiva, removal is comparably easy because the worm is visible through the conjunctiva $[1,8,172,214]$. On the contrary, surgical removal of subcutaneous worms may be unsuccessful, due to the difficulties in precisely locating the parasite.

Medical treatment with anthelminthic drugs, such as albendazole, coupled with doxycycline, was found to stop migration of the worm and promote the formation of a fixed nodule, which can then be removed [136]. The efficacy of such treatment suggests that doxycycline may have a role targeting the endosymbiont Wolbachia, as has been found in dogs [274]. In addition, the immune response of humans to Wolbachia may be used for further confirmation of exposure to the parasite [279].

As soon as $D$. repens is removed, no further medical treatment is required, unless the patient is immunosuppressed or in the extremely rare case of a suspected second nematode $[1,8]$. Because of the rareness of the disease in humans, there are no guidelines or treatment studies and the physician have to rely on their experience. However, either with or without treatment, there is not a single report of a fatality or of permanent body damage.

Prevention of dirofilariosis in humans can be achieved by protecting people from the bites of mosquitoes through the use of repellents and by reducing the prevalence of $D$. repens in dogs, the principal reservoir of the parasite [280].

\section{Potential drivers for the emergence of Dirofilaria repens}

The enhanced dissemination of D. repens in Europe has been primarily attributed to global warming and the 
rapid geographical expansion of some invasive mosquitoes (and/or increases in their density), but also to increased travel and movement of infected animals into non-endemic areas along with a change in human activities $[4,11]$.

The effects of climate change in Europe have been extensively debated [281], since warmer climates could favor mosquito breeding and shorten extrinsic incubation periods [282], thus enhancing the risk of Dirofilaria spp. transmission. The projected increment in temperature will impact on insect vectors through broadening areas of colonization, invasion of new sites and, eventually, resulting in physiological changes and increased vectorial capacity. The most recent example is the finding of Uranotaenia unguiculata, a thermophilic mosquito species frequently occurring in the Mediterranean, in northern Germany, some $300 \mathrm{~km}$ north of previous collection sites [283].

An increase in mean temperatures has affected the mosquito abundance and their seasonal survival in many areas of Europe greatly impacting on the spread of filarial infestation and making most of the European countries suitable for Dirofilaria spp. transmission [284, 285].

A recent climatic model studied the impact of a regional warming (Russia, Ukraine, and other countries of the former USSR) on the spreading of D. repens and the risk of transmission to humans [26]. The model predicted an increase of $18.5 \%$ in transmission area and $10.8 \%$ in population exposure by 2030 .

In addition, several intrinsic factors linked to the specific vector mosquito species also impact on the distribution of $D$. repens. The expansion of dirofilariosis somehow matched the second introduction of Ae. albopictus in Europe (Italy) [286]. Furthermore, over the past decades, $C x . p$. pipiens has changed its endophagic and anthropophagic behavior in central Europe [287], where it also searches for human blood outdoors, close to the houses, as happens in southern parts of the continent.

The introduction of the Pet Travel Scheme in 2000, allowing an easier movement of companion animals throughout the European Union [288], has likely contributed to the diffusion of $D$. repens in Europe. The first case of $D$. repens in a dog resident in UK was recently reported in a dog originated from Romania and was not easily identified [202], thus reactivating the discussion on the implications for establishment and spread of $D$. repens in non-endemic countries.

Once $D$. repens has been introduced in a new area with an infected dog, the availability of suitable hosts for $D$. repens, the presence and density of competent mosquito vectors and their feeding behavior are among the most important factors impacting on its further distribution. Dogs are optimal reservoirs of $D$. repens also because they attract competent mosquito vectors and are quite tolerant to mosquito bites [11]. Prevalence of microfilaraemic dogs and presence and abundance of competent vectors also affect the rate of infestation within a given mosquito population, which in turn is directly related to the risk for a native dog to be infested.

The factors enhancing the exposure of the host to the vector (i.e. the dog's size, the age and especially the outside exposure) may further increase the risk of $D$. repens infestation [2]. The role of cats and foxes as reservoirs is marginal, because these hosts are rarely microfilaraemic [289].

However, the general factors discussed above should have affected the emergence of both $D$. repens and $D$. immitis. Although a few reports have been published until now on the spread of $D$. immitis towards northern Europe [118, 290-292], there is no doubt that D. repens has spread faster than $D$. immitis from the endemic areas of southern European countries and currently it is more prevalent in northern Europe, as confirmed by the emergence of human infections (reviewed in $[4,7,9,27$, 136]. The reasons for this could be linked to the fact that while heartworm infection causes a severe clinical condition in dogs, D. repens in most cases is difficult to diagnose and the course of the infection can be completely asymptomatic. As a consequence, many canine infections can run unnoticed and the infected dog continues to act as a reservoir for competent mosquitoes locally and if transported to non-endemic areas.

In addition, for heartworm infections, several rapid, easy, in clinic whole blood/serological kits are available that detect the circulating antigens of female worms. This allows veterinarians a prompt diagnosis while no serological diagnostic is commercially available for $D$. repens, hampering a rapid screening in dog populations. Blood examination for circulating microfilariae remains the most diffuse test for $D$. repens diagnosis. However, the Knott's test, which allows the visualization and the identification of microfilariae, is not familiar to veterinarians in areas of recent introduction of the parasite. Furthermore, an interaction between the two species of Dirofilaria has been suggested [33], which seems to slow the spread of $D$. immitis in areas where $D$. repens has firstly settled.

Another aspect which deserves attention is the higher prevalence of human infection by $D$. repens compared to D. immitis in Europe, even in countries where the latter is endemic [4]; this is in contrast to the prevalence in the New World, where the human cases of dirofilariosis by $D$. immitis are relatively frequent [293]. There is currently no evidence of a higher virulence of $D$. repens respect to $D$. immitis and of a difference of virulence among strains of the same species, or of a difference in the mosquito vectors of the two parasites. It has been hypothesized that the localization in the subcutaneous tissues may help $D$. repens to escape the natural immune response of unusual hosts, such as humans. 


\section{Conclusions}

There is evidence that $D$. repens has spread faster than $D$. immitis from the endemic areas of southern Europe to northern Europe. Climate change affecting mosquito vectors and the facilitation of pet travel seem to have contributed to this expansion; however, the major factor is likely the rate of undiagnosed dogs perpetuating the life-cycle of $D$. repens. Many infected dogs remain undetected due to the subclinical nature of the disease, the lack of rapid and reliable diagnostic tools and the poor knowledge and still low awareness of D. repens in non-endemic areas. Research and education should fill this gap. Indeed, improved diagnostic tools are warranted to bring $D$. repens diagnosis to the state of $D$. immitis diagnosis, as well as improved screening of imported dogs and promotion of preventative measures among veterinarians and dog owners. In this respect, to transform the disease in a notifiable disease, at least in humans, would help Europe to have official and comparable data on the presence and variations of prevalence among countries. Upcoming studies should also focus on (i) the vector competence and vectorial capacity of mosquito species; (ii) the presence of different genospecies or genotypes of $D$. repens and their specific interactions with hosts and vectors; and (iii) the possible selection of resistance to macrocyclic lactones if preventative measures increase. For vector-borne diseases where an animal species serves as a reservoir, especially a pet, veterinarians play a significant role in prevention and should be more aware of their responsibility in reducing the impact of the zoonotic agents. In addition, they should enhance multisectorial collaboration with medical entomologists and the public health experts, under the concept (and the actions) of One Health-One Medicine.

\section{Additional file}

Additional file 1: Live microfilaria of Dirofilaria repens in the bloodstream of a dog. This movie shows the morphology and movement of the microfilaria of D. repens in a direct blood smear. (MOV $9179 \mathrm{~kb}$ )

\section{Abbreviations}

FYROM: Former Yugoslav Republic of Macedonia; L2: Second larval stage;

L3: Third larval stage; PCR: Polymerase chain reaction

\section{Acknowledgements}

This work was done under the frame of COST action TD1303 (EURNEGVEC).

\section{Funding}

The study was partially funded by the Veneto region, Venice, Italy.

\section{Availability of data and materials}

All data generated and/or analysed during this study are included in this published article and its additional file.

\section{Authors' contributions}

GC, CG, DO and CS assembled the first draft of the review. Authors were responsible for the search of data and references in their respective countries or areas: GB (other mediterranean countries), PB (France), EB, GC, DO, PD and FM (Italy), LC and CM (Portugal and Spain), HPF (Austria), AMI (Romania), DM (Czech Republic), EP (Greece), DP and SS (Balkan area), MP and CS (Germany). CG wrote the hystory of D. repens; LC, CM and GC wrote risk factors; JK wrote the sections on genetics; $A G$ and EB wrote therapy and prevention; DP, FM and CS wrote the sections on vector transmission and competence; SP wrote the parts related to human infections. All authors critically reviewed the manuscript and read and approved the final manuscript.

Ethics approval and consent to participate

Not applicable.

Consent for publication

Not applicable.

\section{Competing interests}

The authors declare that they have no competing interests.

\section{Publisher's Note}

Springer Nature remains neutral with regard to jurisdictional claims in published maps and institutional affiliations.

\section{Author details}

${ }^{1}$ Laboratory of Parasitology, National reference centre/OIE collaborating centre for diseases at the animal-human interface, Istituto Zooprofilattico Sperimentale delle Venezie, Legnaro, Italy. ${ }^{2}$ Department of Veterinary Medicine, Università degli Studi di Milano, Milan, Italy. ${ }^{3}$ Koret School of Veterinary Medicine, The Hebrew University, Rehovot, Israel. ${ }^{4}$ Veterinary School of Nantes ONIRIS, University of Nantes, LUNAM, Nantes, France. ${ }^{5}$ Department of Veterinary Science, Università degli Studi di Messina, Messina, Italy. ${ }^{6}$ Department of Veterinary Sciences, School of Agrarian and Veterinary Sciences, University of Trás-os-Montes e Alto Douro, Vila Real, Portugal. ${ }^{7}$ Institute of Parasitology, University of Veterinary Medicine, Vienna, Austria. ${ }^{8}$ Department of Veterinary Medicine, University of Bari, Valenzano, Italy. ${ }^{9}$ Department of Parasitology and Parasitic Diseases, University of Agricultural Sciences and Veterinary Medicine Cluj-Napoca, Cluj-Napoca, Romania. ${ }^{10} \mathrm{Global}$ Health and Tropical Medicine (GHTM), Instituto de Higiene e Medicina Tropical (IHMT), Universidade Nova de Lisboa (UNL), Lisboa, Portugal. ${ }^{11}$ Department of Pathology and Parasitology, University of Veterinary and Pharmaceutical Sciences, Brno, Czech Republic. ${ }^{12}$ Biology Centre, Institute of Parasitology, Czech Academy of Sciences, České Budějovice, Czech Republic. ${ }^{13}$ Institute for Parasitology and Tropical Veterinary Medicine, Freie Universität Berlin, Berlin, Germany. ${ }^{14}$ Laboratory of Parasitology and Parasitic Diseases, Faculty of Veterinary Sciences, Aristotle University of Thessaloniki, Thessaloniki, Greece. ${ }^{15}$ Laboratory for medical and veterinary entomology, Faculty of Agriculture, University of Novi Sad, Novi Sad, Serbia. ${ }^{16}$ Institute of Animal Hygiene and Veterinary Public Health, Veterinary Faculty, University of Leipzig, Leipzig, Germany. ${ }^{17}$ Scientific Veterinary Institute "Novi Sad", Novi Sad, Serbia. ${ }^{18}$ Swiss Tropical and Public Health Institute, Basel, Switzerland. ${ }^{19}$ University Basel, Basel, Switzerland.

${ }^{20}$ National Centre of Vector Entomology, University of Zurich, Zurich, Switzerland. ${ }^{21}$ Institute of Infectology, Friedrich-Loeffler-Institute, Isle of Riems, Greifswald, Germany.

Received: 19 July 2018 Accepted: 19 November 2018 Published online: 19 December 2018

References

1. Pampiglione S, Rivasi F. Human dirofilariasis due to Dirofilaria (Nochtiella) repens: an update of world literature from 1995 to 2000. Parassitologia. 2000:42:231-54.

2. McCall JW, Genchi C, Kramer LH, Guerrero J, Venco L. Chapter 4. Heartworm disease in animals and humans. Adv Parasitol. 2008;66:193-285.

3. Otranto D, Cantacessi C, Dantas-Torres F, Brianti E, Pfeffer M, Genchi C, et al. The role of wild canids and felids in spreading parasites to dogs and cats in Europe. Part II: Helminths and arthropods. Vet Parasitol. 2015;213:24-37. 
4. Genchi C, Kramer L. Subcutaneous dirofilariosis (Dirofilaria repens): an infection spreading throughout the old world. Parasit Vectors. 2017; 10(Suppl. 2):517.

5. Otranto D, Eberhard ML. Zoonotic helminths affecting the human eye. Parasit Vectors. 2011;4:41.

6. Di Cesare A, Otranto D, Di Giulio E, Simonato G, Latrofa MS, La Torre F, et al. Microfilarial periodicity of Dirofilaria repens in naturally infested dogs. Parasitol Res. 2013;112:4273-9.

7. Sałamatin RV, Pavlikovska TM, Sagach OS, Nikolayenko SM, Kornyushin W, Kharchenko VO, et al. Human dirofilariasis due to Dirofilaria repens in Ukraine, an emergent zoonosis: epidemiological report of 1465 cases. Acta Parasitol. 2013;58:592-8.

8. Pampiglione S, Rivasi F, Angeli G, Boldorini R, Incensati RM, Pastormerlo M, et al. Dirofilariasis due to Dirofilaria repens in Italy, an emergent zoonosis: Report of 60 new cases. Histopathology. 2001;38:344-54.

9. Simón F, Siles-Lucas M, Morchón R, González-Miguel J, Mellado I, Carretón E, et al. Human and animal dirofilariasis: the emergence of a zoonotic mosaic. Clin Microbiol Rev. 2012;25:507-44.

10. Albanese F, Abramo F, Braglia C, Caporali C, Venco L, Vercelli A, et al. Nodular lesions due to infestation by Dirofilaria repens in dogs from Italy. Vet Dermatol. 2013;24:255-e56.

11. Otranto D, Dantas-Torres F, Brianti E, Traversa D, Petrić D, Genchi C, et al. Vectorborne helminths of dogs and humans in Europe. Parasit Vectors. 2013;6:16.

12. Lusitano A. Curationum Medicinalium Centuria Septima. Venetiis: apud Vincentium Valgresium, curatio. 1566;63:106.

13. Pampiglione S, Canestri Trotti G, Rivasi F. Human dirofilariasis due to Dirofilaria (Nochtiella) repens: a review of world literature. Parassitologia. 1995;37:149-93.

14. Addario GG. A nematode of the human eye. Ann Ottalmol. 1885;14:133-7 (in Italian).

15. Skrjabin Kl. Key to Parasitic Nematodes. In: Spirurata and Filariata, vol. 1. Brill: Leiden; 1991.

16. Ercolani G. Helmintological observations on the dimorbiosis of nematodes: on the Filaria immitis and on a new species of dog's distoma. Mem R Acad Sci Ist Bol. 1874;3:390-441 (in Italian).

17. Fulleborn F. Über Versuche an Hundefilarien und deren übertrangung durch Müncken. Arch Schiffs Tropenhyg. 1908;8:313-59.

18. Lanzillotti-Bonsanti A. On the alterations that produce the embryos of Filaria immitis and on a cyst with Filaria immitis in the intermuscular connective of a dog. Clin Vet. 1881;4:212-5 (In Italian).

19. Grassi B, Noè $G$. The propagation of the filariæ of the blood exclusively by means of the puncture of peculiar mosquitos. Br Med J. 1900;2:1306-7.

20. Bonvicini A. Of a case of filariasis in a dog suffering from demodectic mange. Mod Zoiatra Parte Sci. 1910;42:55 (In Italian).

21. Bernard P, Bauche J. Conditions de propagation de la filariose sous-cutanée du chien. Stegomyia fasciata hote intermédiaire de Dirofilaria repems. Bull Soc Pathol Exot. 1913;7:89-99.

22. Rivolta S. Herpes form in the dog produced by embryos of filaria. Med Vet G Teor. 1868;3:300-2 (In Italian).

23. Rosso G. Dog's cutaneous helminthiasis. A case of general pustular dermatitis caused by embryos of Filaria immitis. Mod Zooiatro. 1897;8:185-8 (In Italian).

24. Mazzanti E. Two zooparasitological observations. Observation first on a herpetic affection in a dog produced by nematodes. G R Soc Vet. 1900;50: 626-9 (In Italian).

25. Perez-Sanchez R, Gomez-Bautista M, Grandes AE. Canine filariasis in Salamanca (northwest Spain). Ann Trop Med Parasitol. 1989;83:143-50.

26. Kartashev V, Afonin A, González-Miguel J, Sepúlveda R, Simón L, Morchón R, et al. Regional warming and emerging vector-borne zoonotic dirofilariosis in the Russian Federation, Ukraine, and other post-soviet states from 1981 to 2011 and projection by 2030. Biomed Res Int. 2014;2014:858936.

27. Tasić-Otašević SA, Trenkić Božinović MS, Gabrielli SV, Genchi C. Canine and human Dirofilaria infections in the Balkan Peninsula. Vet Parasitol. 2015;209: 151-6.

28. Fuehrer HP, Auer H, Leschnik M, Silbermayr K, Duscher G, Joachim A. Dirofilaria in humans, dogs, and vectors in Austria (1978-2014). From imported pathogens to the endemicity of Dirofilaria repens. PLoS Negl Trop Dis. 2016;10:e0004547.

29. Kartashev V, Tverdokhlebova T, Korzan A, Vedenkov A, Simón L, GonzálezMiguel J, et al. Human subcutaneous/ocular dirofilariasis in the Russian Federation and Belarus, 1997-2013. Int J Infect Dis. 2015;33:209-11.
30. Kottek M, Grieser J, Beck C, Rudolf B, Rubel F. World map of the KöppenGeiger climate classification updated. Meteorol Zeitschrift. 2006;15:259-63.

31. Balbo T, Panichi M. Filariosis in the dog. Nuova Vet. 1968;44:18-32 (In Italian).

32. Locatelli A. On the animal filariosis in the province of Pavia. Parassitologia. 1971;13:197-202 (In Italian)

33. Genchi C, Rinaldi L, Cascone C, Mortarino M, Cringoli G. Is heartworm disease really spreading in Europe? Vet Parasitol. 2005;133:137-48.

34. Scaramozzino P, Gabrielli S, Di Paolo M, Sala M, Scholl F, Cancrini G. Dog filariosis in the Lazio region (Central Italy): first report on the presence of Dirofilaria repens. BMC Infect Dis. 2005;5:75.

35. Traversa D, Aste G, Milillo P, Capelli G, Pampurini F, Tunesi C, et al. Autochthonous foci of canine and feline infections by Dirofilaria immitis and Dirofilaria repens in central Italy. Vet Parasitol. 2010;169:128-32.

36. Magi M, Guardone L, Prati MC, Tozzini G, Torracca B, Monni G, et al. Canine filarial infections in Tuscany, central Italy. J Helminthol. 2012;86:113-6.

37. Magi M, Guardone L, Mignone W, Monni G, Tozzini G, Prati MC, et al. Canine filarial infections in Liguria, north-west Italy. J Helminthol. 2016;90:121-4.

38. Otranto D, Testini G, Dantas-Torres F, Latrofa MS, De Paiva Diniz PPV, De Caprariis $\mathrm{D}$, et al. Diagnosis of canine vector-borne diseases in young dogs: a longitudinal study. J Clin Microbiol. 2010;48:3316-24.

39. Otranto D, Capelli G, Genchi C. Changing distribution patterns of canine vector borne diseases in Italy: leishmaniosis vs. dirofilariosis. Parasit Vectors. 2009;2(Suppl. 1):S2.

40. Giangaspero A, Marangi M, Latrofa MS, Martinelli D, Traversa D, Otranto D, et al. Evidences of increasing risk of dirofilarioses in southern Italy. Parasitol Res. 2013;112:1357-61.

41. Latrofa MS, Montarsi F, Ciocchetta S, Annoscia G, Dantas-Torres F, Ravagnan $S$, et al. Molecular xenomonitoring of Dirofilaria immitis and Dirofilaria repens in mosquitoes from north-eastern Italy by real-time PCR coupled with melting curve analysis. Parasit Vectors. 2012;5:76.

42. Pampiglione S, Rivasi F, Gustinelli A. Dirofilarial human cases in the Old World, attributed to Dirofilaria immitis: a critical analysis. Histopathology. 2008;53:746-7.

43. Baneth G, Bourdeau P, Bourdoiseau G, Bowman D, Breitschwerdt E, Capelli $G$, et al. Vector-borne diseases - constant challenge for practicing veterinarians: recommendations from the CVBD World Forum. Parasit Vectors. 2012;5:55.

44. Otranto D, Brianti E, Gaglio G, Dantas-Torres F, Azzaro S, Giannetto S. Human ocular infection with Dirofilaria repens (Railliet and Henry, 1911) in an area endemic for canine dirofilariasis. Am J Trop Med Hyg. 2011;84:1002-4.

45. Giannetto S, Pampiglione S, Santoro V, Virga A. Research of canine filariasis in Trapani province (western Sicily). Morphology on SEM of male Dirofilaria repens. Parassitologia. 1997;39:403-5.

46. Rojo-Vázquez F, Valcárcel F, Guerrero J, Gómez M. Prevalencia de la dirofilariosis canina en cuatro áreas geográficas de España. Med Vet Barcelona. 1990;7:297-305

47. Cancrini G, Allende E, Favia G, Bornay F, Antón F, Simón F. Canine dirofilariosis in two cities of southeastern Spain. Vet Parasitol. 2000;92:81-6.

48. Logar J, Novsak V, Rakovec S, Stanisa O. Subcutaneous infection caused by Dirofilaria repens imported to Slovenia. J Infect. 2001;42:72-4.

49. Fuentes I, Cascales A, Ros JM, Sansano C, Gonzalez-Arribas JL, Alvar J. Human subcutaneous dirofilariasis caused by Dirofilaria repens in Ibiza. Spain Am J Trop Med Hyg. 1994;51:401-4.

50. Ruiz-Moreno J, Bornay-Llinares F, Prieto Maza G, Medrano M, Simón F, Eberhard M. Subconjunctival infection with Dirofilaria repens: serological confirmation of cure following surgery. Arch Ophthalmol. 1998;116:1370-2.

51. Maia C, Lorentz S, Cardoso L, Otranto D, Naucke TJ. Detection of Dirofilaria repens microfilariae in a dog from Portugal. Parasitol Res. 2016;115:441-3.

52. Baptista-Fernandes $T$, Rodrigues $M$, Domingues $D$, Monteiro $L$, Paixao $P$, Pereira $P$, et al. Dirofilariasis by Dirofilaria repens: an imported case and a brief review. Parasitol Int. 2015;64:261-3.

53. Papazahariadou MG, Koutinas AF, Rallis TS, Haralabidis ST. Prevalence of microfilaraemia in episodic weakness and clinically normal dogs belonging to hunting breeds. J Helminthol. 1994;68:243-5.

54. Diakou A, Kapantaidakis E. Epidemiology of dirofilariosis in dogs in Greece: previous and latest information. In: Fourth European Dirofilaria Angiostrongylus Days. Budapest; 2014. p. 44.

55. Diakou A, Kapantaidakis E, Tamvakis A, Giannakis V, Strus N. Dirofilaria infections in dogs in different areas of Greece. Parasit Vectors. 2016;9:508.

56. Pampiglione S, Rivasi F, Vakalis N. Human pulmonary dirofilariasis: the first case observed in Greece. Ann. Pathol. 2000;20:626-8. 
57. Klintebjerg K, Larsen CS, Heje M. Dirofilaria repens in a Danish woman after traveling to Crete. Ugeskr Laeger. 2016;178:V67956 (In Danish).

58. Ducos de Lahitte J. Epidemiology of filariases in France. Prat Médicale Chir l'Animal. 1990;25:305-10.

59. Bourdeau P, Roussel A. Canine infection with Dirofilaria repens in France: distribution and prevalence from a national survey with veterinary clinics. Melbourne: Proceedings ICOPA XII; 2010.

60. Raccurt CP. Human dirofilariasis in France: new data confirming the human transmission of Dirofilaria repens to the north of the 46 degree north latitude. Med Trop. (Mars). 2000;60:308-9.

61. de Vries PJ, Visser LG, Vetter HCM, Muller HP, Polderman AM. Migrating subcutaneous swellings due to dirofilariasis after a visit to the South of France. Ned Tijdschr Geneeskd. 2003;147:566-9.

62. Estran C, Marty P, Blanc V, Faure O, Leccia M-T, Pelloux H, et al. Dirofilariose humaine: 3 cas autochtones dans le sud de la France. Press Med. 2006;36:799-803.

63. Abou-Bacar A, Diallo M, Waller J, Cribier B, Candolfi E. Human subcutaneous dirofilariosis due to Dirofilaria repens. A case diagnosed in Strasbourg, France. Bull Soc Pathol Exot. 2007;100:269-70.

64. Perret-Court A, Coulibaly B, Ranque S, Bouvier C, Lena G, Coze C, et al. Intradural dirofilariasis mimicking a Langerhans cell histiocytosis tumor. Pediatr Blood Cancer. 2009;53:485-7.

65. Leccia N, Patouraux S, Carpentier X, Boissy C, Del Giudice P, Parks S, et al. Pseudo-tumor of the scrotum, a rare clinical presentation of dirofilariasis: a report of two autochtonous cases due to Dirofilaria repens. Pathog Glob Health. 2012;106:370-2.

66. de Boysson H, Duhamel C, Heuzé-Lecornu L, Bonhomme J, de La Blanchardière A. Dirofilariose humaine: Un nouveau cas français à Dirofilaria repens. Rev Med Interne. 2012;33:e19-21.

67. Blaizot $R$, Receveur M-C, Millet $P$, Otranto D, Malvy DJM. Systemic infection with Dirofilaria repens in southwestern France. Ann Intern. Med. 2018;168:228-9.

68. Nozais JP, Bain O, Gentilini M. A case of subcutaneous Dirofilaria (Nochtiella) repens with microfilaremia originating in Corsica. Bull Soc Pathol Exot. 1994; 87:183-5.

69. Tahir D, Bittar F, Barré-Cardi H, Sow D, Dahmani M, Mediannikov O, et al. Molecular survey of Dirofilaria immitis and Dirofilaria repens by new real-time TaqMan ${ }^{\oplus}$ PCR assay in dogs and mosquitoes (Diptera: Culicidae) in Corsica (France). Vet Parasitol. 2017;235:1-7.

70. Deplazes P, Guscetti F, Wunderlin E, Bucklar H, Skaggs J, Wolff K Endoparasite infection in stray and abandoned dogs in southern Switzerland. Schweiz Arch Tierheilkd. 1995;137:172-9.

71. Petruschke G, Rossi L, Genchi C, Pollono F. Canine dirofilariasis in the canton of Ticino and in the neighboring areas of northern Italy. Schweiz Arch Tierheilkd. 2001;143:141-7.

72. Hasler S, Grimm F, Thiel MA, Müller NJ, Eberhard R, Bosch MM. Swiss patient with a subconjunctival Dirofilaria repens. Klin Monbl Augenheilkd. 2010;227:332-3.

73. Hermosilla C, Pantchev N, Dyachenko V, Gutmann M, Bauer C. First autochthonous case of canine ocular Dirofilaria repens infection in Germany. Vet Rec. 2006;158:134-5.

74. Pantchev N, Schaper R, Limousin S, Norden N, Weise M, Lorentzen L. Occurrence of Dirofilaria immitis and tick-borne infections caused by Anaplasma phagocytophilum, Borrelia burgdorferi sensu lato and Ehrlichia canis in domestic dogs in France: results of a countrywide serologic survey. Parasitol Res. 2009;105(Suppl. 1):S101-14.

75. Sassnau R, Dyachenko V, Pantchev N, Stöckel F, Dittmar K, Daugschies A. Dirofilaria repens-Befall in einem Schlittenhunde-Rudel im Land Brandenburg-Diagnose und Therapie der kaninen kutanen Dirofilariose. Tierärztliche Prax. 2009;37:95-101.

76. Sassnau R, Kohn M, Demeler J, Kohn B, Müller E, Krücken J, et al. Is Dirofilaria repens endemic in the Havelland district in Brandenburg, Germany? Vector Borne Zoonotic Dis. 2013;13:888-91.

77. Liesner JM, Krücken J, Schaper R, Pachnicke S, Kohn B, Müller E, et al. Vectorborne pathogens in dogs and red foxes from the federal state of Brandenburg, Germany. Vet Parasitol. 2016;224:44-51.

78. Stock I. Dirofilaria repens detected in mosquitoes in Germany for the first time. Med Monatsschr Pharm. 2013;36:351-3.

79. Czajka C, Becker N, Jöst H, Poppert S, Schmidt-Chanasit J, Krüger A, et al. Stable transmission of Dirofilaria repens nematodes, northern Germany. Emerg Infect Dis. 2014;20:328-31.

80. Kronefeld M, Kampen H, Sassnau R, Werner D. Molecular detection of Dirofilaria immitis, Dirofilaria repens and Setaria tundra in mosquitoes from Germany. Parasit Vectors. 2014;7:30.
81. Sassnau R, Czajka C, Kronefeld M, Werner D, Genchi C, Tannich E, et al. Dirofilaria repens and Dirofilaria immitis DNA findings in mosquitoes in Germany: temperature data allow autochthonous extrinsic development. Parasitol Res. 2014;113:3057-61.

82. Tappe D, Plauth M, Bauer T, Muntau B, Dießel L, Tannich E, et al. A case of autochthonous human Dirofilaria infection, Germany, March 2014. Euro Surveill. 2014;19:2-4.

83. Overgaauw P, van Dijk E. Autochthonous case of Dirofilaria repens in a dog in the Netherlands. Vet Rec. 2009;164:158.

84. Auer $\mathrm{H}$, Susani M. The first autochthonous case of subcutaneous dirofilariosis in Austria. Wien Klin Wochenschr. 2008:120:104-6.

85. Silbermayr K, Eigner B, Joachim A, Duscher GG, Seidel B, Allerberger F, et al. Autochthonous Dirofilaria repens in Austria. Parasit Vectors. 2014;7:226.

86. Demiaszkiewicz A, Polanczyk G, Pyziel A. The first outbreaks of dogs dirofilariosis caused by Dirofilaria repens Railliet et Henry, 1911 in central Poland. Wiadomości Parazytologiczne. 2009;55:367-70 (In Polish).

87. Demiaszkiewicz AW. Dirofilaria repens Railliet et Henry, 1911 - a new parasite acclimatized in Poland. Ann Parasitol. 2014;60:31-5.

88. Bajer A, Rodo A, Mierzejewska EJ, Tołkacz K, Welc-Faleciak R. The prevalence of Dirofilaria repens in cats, healthy dogs and dogs with concurrent babesiosis in an expansion zone in central Europe. BMC Vet Res. 2016;12:183.

89. Zarnowska-Prymek H, Cielecka D, Salamatin R. Dirofilariasis - Dirofilaria repens - first time described in Polish patients. Przegl Epidemiol. 2008;62: 547-51 (In Polish)

90. Cielecka D, Zarnowska-Prymek H, Masny A, Salamatin R, Wesołowska M, Gołab E. Human dirofilariosis in Poland: the first cases of autochthonous infections with Dirofilaria repens. Ann Agric Environ Med. 2012;19:445-50.

91. Svobodová Z, Svobodova V, Genchi C, Forejtek P. The first report of authochthonous dirofilariosis in dogs in the Czech Republic. Helminthologia. 2006;4:242-5.

92. Dobešová R, Svobodova V. Progressive spread of Dirofilaria infections in dogs along rivers in the southeastern Czech Republic. In: Second European Dirofilaria Days. Salamanca; 2009.

93. Matějů J, Chanová M, Modrý D, Mitková B, Hrazdilová K, Žampachová V, Kolárová L. Dirofilaria repens: emergence of autochthonous human infections in the Czech Republic (case reports). BMC Infect Dis. 2016;16:171.

94. Fok É, Szaboó Z, Farkas R. The first autochthonous case of a dog infected with Dirofilaria repens. Kisállatorvoslás. 1998:4:218-9 (In Hungarian).

95. Fok É, Kiss G, Majoros G, Jacsó O, Farkas R, Gyurkovszky M. Preliminary results of an epidemiological survey on dirofilariosis of dogs and cats in Hungary. Mappe Parassitol. 2007;8:195-6.

96. Jacsó O, Kiss G, Krassóvári D, Kiss H, Gyurkovszky M. Epidemiological view about dirofilarioses in dogs of Hungary. In: Fourth European Dirofilaria Angiostrongylus Days (FEDAD). Budapest; 2014.

97. Pónyai K, Wikonkál N, Bottlik G, Hársing J, Kucsera I, Horváth A, et al. Dirofilaria repens infection case in Hungary: a case report. J Dtsch Dermatol Ges. 2006:4:1051-3.

98. Szénási Z, Kovács AH, Pampiglione S, Fioravanti ML, Kucsera I, Tánczos B, et al. Human dirofilariosis in Hungary: an emerging zoonosis in central Europe. Wien Klin Wochenschr. 2008;120:96-102.

99. Révész E, Markovics G, Darabos Z, Tóth I, Fok E. Dirofilaria in the abdominal cavity. Magy Seb. 2008:61:281-4.

100. Fodor $E$, Fok E, Maka $E$, Lukats $\mathrm{O}$, Toth J. Recently recognized cases of ophthalmofilariasis in Hungary. Eur J Ophthalmol. 2009;19:675-8.

101. Dóczi I, Bereczki L, Gyetvai T, Fejes I, Skribek Á, Szabó Á, et al. Description of five dirofilariasis cases in South Hungary and review epidemiology of this disease for the country. Wien Klin Wochenschr. 2015;127:696-702.

102. Holler D, Racz A, Bošnir J, Petrak $O$. The prevalence of dirofilariasis in the hinterland of the Istrian Peninsula. Medica Jadertina. 2011;40:67-74.

103. Jurhar-Pavlova M, Cvetković D, Duma H, Kochevski Z. Dirofilariasis in R. Macedonia an overview of literature data and our expirience, vol. 2012. Niš: 46th Days of Preventive Medicine, International Congress, Book of Abstracts; 2012. p. 130-2.

104. Pantchev N, Etzold M, Daugschies A, Dyachenko V. Diagnosis of imported canine filarial infections in Germany 2008-2010. Parasitol Res. 2011;109:61-76.

105. Tasić A, Tasić-Otašević S, Gabrielli S, Miladinović-Tasić N, Ignjatović A, Đorđević J, et al. Canine Dirofilaria infections in two uninvestigated areas of Serbia: epidemiological and genetic aspects. Vector Borne Zoonotic Dis. 2012;12:1031-5.

106. Ćirović D, Penezić A, Pavlović I, Kulišić Z, Cosić N, Burazerović J, et al. First records of Dirofilaria repens in wild canids from the region of central Balkan. Acta Vet Hung. 2014;62:481-8. 
107. Dzamić AM, Arsić-Arsenijević V, Radonjić I, Mitrović S, Marty P, Kranjcić-Zec IF. Subcutaneous Dirofilaria repens infection of the eyelid in Serbia and Montenegro. Parasite. 2004;11:239-40.

108. Tasić S, Stoiljković N, Miladinović-Tasić N, Tasić A, Mihailović D, Rossi L, et al. Subcutaneous dirofilariosis in south-east Serbia - case report. Zoonoses Public Health. 2011:58:318-22.

109. Krstić M, Gabrielli S, Ignjatović M, Savić S, Cancrini G, Ranđelović G, et al. An appraisal of canine and human cases reveals an endemic status of dirofilariosis in parts of Serbia. Mol Cell Probes. 2017;31:37-41.

110. Janjetović Z, Arar ZV, Paradzik MT, Sapina L, Bitunjac M, Lojen G, et al. Ocular dirofilariasis: a case report. Acta Med Croatica. 2010;64:41-5.

111. Marusić Z, Stastny T, Kirac I, Stojcević D, Kruslin B, Tomas D. Subcutaneous dirofilariasis caused by Dirofilaria repens diagnosed by histopathologic and polymerase chain reaction analysis. Acta Dermatovenerol Croat. 2008;16:222-5.

112. Bezić J. Human dirofiliariasis in Croatia. Acta Dermatovenerol Croat. 2009;17:82-3.

113. Ritter A, Egger S, Emesz M. Dirofilariose: Subkonjunktivale Infektion mit Dirofilaria repens. Ophthalmologe. 2012;109:788-90.

114. Radovanovic Spurnic AP, Stevanovic G, Dakic Z, Ofori Belic I, Spurnic I, Pelemis M. Human subcutaneous dirofilariasis - case report. Med Pregl. 2015;68:273-6.

115. Kanev I, Kamenov I, Ganchev G, Prelezov P, Tzvetkov Y, Tomcheva V, et al. Dirofilaria repens and Dirofilaria immitis in animals and humans in Bulgaria. Parassitologia. 1996;38:358.

116. Harizanov RN, Jordanova DP, Bikov IS. Some aspects of the epidemiology, clinical manifestations, and diagnosis of human dirofilariasis caused by Dirofilaria repens. Parasitol Res. 2014;113:1571-9.

117. Svobodova V, Svobodova Z, Beladicova V, Valentova D. First cases of canine dirofilariosis in Slovakia: a case report. Vet Med (Praha). 2005;50:510-2.

118. Miterpáková M, Antolová D, Hurníková Z, Dubinský P, Pavlacka A, Németh J. Dirofilaria infections in working dogs in Slovakia. J Helminthol. 2010;84:173-6.

119. Iglódyová A, Miterpáková M, Hurníková Z, Antolová D, Dubinský P, Letková V. Canine dirofilariosis under specific environmental conditions of the Eastern Slovak Lowland. Ann Agric Environ Med. 2012;19:57-60.

120. Babal P, Kobzova D, Novak I, Dubinsky P, Jalili N. First case of cutaneous human dirofilariosis in Slovak Republic. Bratisl Lek Listy. 2008;109:486-8.

121. Ondriska F, Lengyel D, Miterpáková M, Lengyelová B, Strehárová A, Dubinský P. Human dirofilariosis in the Slovak Republic - a case report. Ann Agric Env Med. 2010;17:169-71.

122. Hrčkova G, Kuchtová H, Miterpáková M, Ondriska F, Cibíček J, Kovacs S. Histological and molecular confirmation of the fourth human case caused by Dirofilaria repens in a new endemic region of Slovakia. J Helminthol. 2013;87:85-90

123. Miterpáková M, Antolová D, Ondriska F, Gál V. Human Dirofilaria repens infections diagnosed in Slovakia in the last 10 years (2007-2017). Wien Klin Wochenschr. 2017;129:634-41.

124. Čabanová V, Miterpáková M, Valentová D, Blažejová H, Rudolf I, Stloukal E, et al. Urbanization impact on mosquito community and the transmission potential of filarial infection in central Europe. Parasit Vectors. 2018;11:261.

125. Olteanu G. Dirofilariosis in man and animals in Romania. Parassitologia. 1996;38(Suppl. 1-2):360.

126. Paşca S, Miron L, Acatrinei D, Mihalachi S. Both cardio-vasculary and subcutaneous forms of dirofilariosis in dog: a case report. Sci Papers Vet Med lași. 2008;51:123-7.

127. Ciocan R, Darăbuș G, Jascó O, Fok É. Detection of Dirofilaria spp. in dogs by PCR. Bull USAMV. 2010;67:40-4.

128. Ciocan R, Mederle N, Jacsó O, Tánczos B, Fok É. Autochthonous cases of Dirofilaria in dogs from Timiș County (Western Part) Romania. Glob J Med Res. 2013;13:1-6.

129. Ionică AM, Matei IA, Mircean V, Dumitrache MO, D'Amico G, Győrke A, et al. Current surveys on the prevalence and distribution of Dirofilaria spp. and Acanthocheilonema reconditum infections in dogs in Romania. Parasitol Res. 2015;114:975-82.

130. Mănescu R, Bărăscu D, Mocanu C, Pîrvănescu H, Mîndriă I, Bălăşoiu M, et al. Subconjunctival nodule with Dirofilaria repens. Chirurgia (Bucur). 2009;104: 95-7 (In Romanian).

131. Popescu I, Tudose I, Racz P, Muntau B, Giurcaneanu C, Poppert S. Human Dirofilaria repens infection in Romania: a case report. Case Rep Infect Dis. 2012;2012:472976.

132. Arbune $M$, Dobre M. Dirofilariasis - an emergent human parasitosis in Romania. Acta Parasitol. 2015;60:485-7.

133. Macarie SS, Dobre C, Suciu M-C, Ionica A-M, Cernea M-S, Tarcău P, et al. Subconjunctival ocular filariasis - case report. Rom J Ophthalmol. 2017;61:76-9.
134. Artamonova A. Cases of dirofilariasis in the Rostov Region. In: Helminthiasis in Humans. St Petersburg: VMedA Editors; 1989. p. 92-5.

135. Kartashev V, Batashova I, Kartashov S, Ermakov A, Mironova A, Kuleshova Y, et al. Canine and human dirofilariosis in the Rostov Region (southern Russia). Vet Med Int. 2011;2011:685713.

136. Ermakova LA, Nagorny SA, Krivorotova EY, Pshenichnaya NY, Matina ON. Dirofilaria repens in the Russian Federation: current epidemiology, diagnosis, and treatment from a federal reference center perspective. Int J Infect Dis. 2014:23:47-52.

137. Hamel D, Silaghi C, Zapadynska S, Kudrin A, Pfister K. Vector-borne pathogens in ticks and EDTA-blood samples collected from client-owned dogs, Kiev, Ukraine. Ticks Tick Borne Dis. 2013;4:152-5.

138. Kramer LH, Kartashev W, Grandi G, Morchón R, Nagornii SA, Karanis P, et al. Human subcutaneous dirofilariasis, Russia. Emerg Infect Dis. 2007;13:150-2.

139. Bartkova AD, Poliakova LF, Ermolenko AV. Human dirofilariasis in the Primorye Territory. Med Parazitol. (Mosk). 2011;1:47-8 (In Russian).

140. Supriaga VG, Darchenkova NN, Bronshteĭn AM, Lebedeva MN, lastreb VB, Ivanova TN, et al. Dirofilariasis in the Moscow Region, a low disease transmission risk area. Med Parazitol (Mosk). 2011;1:3-7 (In Russian).

141. Belova NE. Dirofilariasis in the Nizhny Novgorod Region. Med Parazitol (Mosk). 2012;2:18-20 (In Russian).

142. Derzhavina TI, Boldyreva W, Sheveleva OF, Gribova TI, Chernysheva AA, Chernikova EA. A dirofilariasis focus in the Tula Region in 2011. Med Parazitol (Mosk). 2012;2:50 (In Russian).

143. Nagornyi SA, Ermakova LA, Krivorotova El. The specific features of the epidemiology and epizootology of dirofilariasis in Rostov-on-Don and the Rostov Region. Med Parazitol (Mosk). 2012;2:46-8 (In Russian).

144. Rosolovskii AP, P'ianykh VA, Ignat'eva VI, Matina ON, Shevchuk EA, Danilova EP, et al. Dirofilariasis in the Nizhny Novgorod Region. Med Parazitol (Mosk). 2013;1:34-5 (In Russian).

145. Ivanova IB, Trotsenko OE, Karavianskaia TN, Ganushkina LA. Human dirofilariasis in the city of Khabarovsk. Med Parazitol (Mosk). 2013;3:18-20 (In Russian).

146. Fedianina LV, Shatova SM, Rakova VM, Shătanov VM, Lebedeva MN, Frolova AA, et al. Microfilaraemia in human dirofilariasis caused by Dirofilaria repens Railliet et Henry, 1911. A case report. Med Parazitol (Mosk). 2013;2:3-7 (In Russian).

147. Ilyasov B, Kartashev V, Bastrikov N, Madjugina L, González-Miguel J, Morchón $\mathrm{R}$, et al. Thirty cases of human subcutaneous dirofilariasis reported in Rostov-on-Don (southwestern Russian Federation). Enferm Infecc Microbiol Clin. 2015;33:233-7.

148. Supryaga VG, Rakova VM, Morozov EN. Current ideas on obligate and facultative relationships between man and the dirofilariasis pathogen Dirofilaria (N.) repens. Med Parazitol (Mosk). 2016;2:3-7 (In Russian).

149. Masny A, Sałamatin R, Cielecka D, Kharchenko VO, Conn DB, Golab E. Human dirofilariasis due to Dirofilaria repens in the Russian Federation remarks concerning epidemiology. Int J Infect Dis. 2014;28:225.

150. Rossi A, Peix A, Pavlikovskaya T, Sagach O, Nikolaenko S, Chizh N, et al. Genetic diversity of Dirofilaria spp. isolated from subcutaneous and ocular lesions of human patients in Ukraine. Acta Trop. 2015;142:1-4.

151. Ermakova L, Nagorny S, Pshenichnaya N, Ambalov Y, Boltachiev K. Clinical and laboratory features of human dirofilariasis in Russia. IDCases. 2017;9:112-5.

152. Bogacheva AS, Ganushkina LA, Lopatina YV. Infection of blood-sucking mosquitoes (Diptera: Culicidae) with dirofilariae (Spirurida, Onchocercidae) in the Tula region. Med Parazitol (Mosk). 2016;2:8-12 (In Russian).

153. Șuleșco $T$, von Thien $H$, Toderaș L, Toderaș I, Lühken R, Tannich E. Circulation of Dirofilaria repens and Dirofilaria immitis in Moldova. Parasit Vectors. 2016;9:627.

154. Jokelainen P, Mõtsküla PF, Heikkinen P, Ülevaino E, Oksanen A, Lassen B. Dirofilaria repens microfilaremia in three dogs in Estonia. Vector Borne Zoonotic Dis. 2016;16:136-8.

155. Melbarde-Gorkusa I, Abolins A, Strumfa I, Martinsons A, Gardovskis J. Human dirofilariasis in Latvia - the first case in surgical practice. Acta Chir Latv. 2011;11:172-4.

156. Tiškina $V$, Jokelainen $P$. Vector-borne parasitic infections in dogs in the Baltic and Nordic countries: a questionnaire study to veterinarians on canine babesiosis and infections with Dirofilaria immitis and Dirofilaria repens. Vet Parasitol. 2017;244:7-11.

157. Pietikäinen R, Nordling S, Jokiranta S, Saari S, Heikkinen P, Gardiner C, et al. Dirofilaria repens transmission in southeastern Finland. Parasit Vectors. 2017;10:561.

158. Abdel-Rahman SM, Mahmoud AE, Galal LAA, Gustinelli A, Pampiglione S. Three new cases of human infection with Dirofilaria repens, one pulmonary and two subcutaneous, in the Egyptian governorate of Assiut. Ann Trop Med Parasitol. 2008;102:499-507. 
159. Rjeibi MR, Rouatbi M, Mabrouk M, Tabib I, Rekik M, Gharbi M. Molecular study of Dirofilaria immitis and Dirofilaria repens in dogs from Tunisia. Transbound Emerg Dis. 2017;64:1505-9.

160. Baneth G, Volansky Z, Anug Y, Favia G, Bain O, Goldstein RE, et al. Dirofilaria repens infection in a dog: diagnosis and treatment with melarsomine and doramectin. Vet Parasitol. 2002;105:173-8.

161. Raniel Y, Machamudov Z, Garzozi HJ. Subconjunctival infection with Dirofilaria repens. Isr Med Assoc J. 2006;8:139.

162. Tarish JH, Al-Saqur IM, Al-Abbassy SN, Kadhim FS. The prevalence of parasitic helminths in stray dogs in the Baghdad area, Iraq. Ann Trop Med Parasitol. 1986;80:329-31.

163. Tarello W. Dermatitis associated with Dirofilaria repens microfilariae in three dogs in Saudi Arabia. J Small Anim Pract. 2003:44:132-4.

164. Tarello W. Dermatitis associated with Dirofilaria repens microfilariae in a dog in Dubai. Vet Rec. 2002;151:738-9.

165. Tarello W. Autochthonous Dirofilaria (Nochtiella) repens infection in dogs in Kuwait. Zoonoses Public Health. 2008:55:328-30.

166. Ashrafi K, Golchai J, Geranmayeh S. Human subcutaneous dirofilariasis due to Dirofilaria (Nochtiella) repens: clinically suspected as cutaneous fascioliasis. Iran J Public Health. 2010;39:105-9.

167. Latifoğlu O, Özmen S, Sezer C, Yavuzer R, Altintaş K, Uluoǧlu Ö. Dirofilaria repens presenting as a premasseteric nodule. Oral Surg Oral Med Oral Pathol Oral Radiol Endod. 2002:94:217-20.

168. Beden U, Hokelek M, Acici M, Umur S, Gungor I, Sullu Y. A case of orbital dirofilariasis in northern Turkey. Ophthal Plast Reconstr Surg. 2007;23:329-31.

169. Yaman M, Guzel M, Koltas IS, Demirkazik M, Aktas H. Prevalence of Dirofilaria immitis in dogs from Hatay Province, Turkey. J Helminthol. 2009;83:255-60.

170. Ranjbar-Bahadori S, Veshgini A, Shirani D, Eslami A, Mohieddin H, Shemshadi B, et al. Epidemiological aspects of canine dirofilariasis in the north of Iran. Iran J Parasitol. 2011;6:73-80.

171. Yilmaz E, Fritzenwanker M, Pantchev $N$, Lendner M, Wongkamchai S, Otranto $D$, et al. The mitochondrial genomes of the zoonotic canine filarial parasites Dirofilaria (Nochtiella) repens and Candidatus Dirofilaria (Nochtiella) honkongensis provide evidence for presence of cryptic species. PLoS Negl Trop Dis. 2016;10:e0005028

172. Winkler S, Pollreisz A, Georgopoulos M, Bagò-Horvath Z, Auer H, To KK-W, et al. Candidatus Dirofilaria hongkongensis as causative agent of human ocular filariosis after travel to India. Emerg Infect Dis. 2017;23:1428-31.

173. Bain O. Développment en Camargue de la filaire du chien, Dirofilaria repens Railliet at Henry, 1911, chez les Aedes halophile. Bull Mus Nat Hist Nat. 1978:351:19-27.

174. Cancrini G, Yanchang S, Della Torre A, Coluzzi M. Influence of temperature on the larval development of Dirofilaria repens in different species of mosquitoes. Parassitologia. 1988;30:38 (In Italian).

175. Webber W, Hawking F. Experimental maintenance of Dirofilaria repens and D. immitis in dogs. Exp Parasitol. 1955;4:143-64.

176. Anyanwu IN, Agbede RIS, Ajanusi OJ, Umoh JU, Ibrahim NDG. The incrimination of Aedes (Stegomyia) aegypti as the vector of Dirofilaria repens in Nigeria. Vet Parasitol. 2000;92:319-27.

177. Cancrini G, Scaramozzino P, Gabrielli S, Di Paolo M, Toma L, Romi R. Aedes albopictus and Culex pipiens implicated as natural vectors of Dirofilaria repens in central Italy. J Med Entomol. 2007:44:1064-6.

178. Petry G, Genchi M, Schmidt H, Schaper R, Lawrenz B, Genchi C. Evaluation of the adulticidal efficacy of imidacloprid $10 \% /$ moxidectin $2.5 \%(\mathrm{~W} / \mathrm{v})$ spoton (Advocate ${ }^{\circledR}$, Advantage ${ }^{\circledR}$ Multi) against Dirofilaria repens in experimentally infected dogs. Parasitol Res. 2015:114:131-44.

179. Khudaverdiev T. The biology Dirofilaria repens repens Railliet and Henry, 1911, the causal agent of dirofilariasis of dogs in the Nakhichevan Republic, ASSR. Mater Nauchnoi Konf Vsesoyuznogo Obs Gelmintol Russ. 1976;28: 163-9 (In Russian)

180. Cancrini G, Magi M, Gabrielli S, Arispici M, Tolari F, Dell'Omodarme M, et al. Natural vectors of dirofilariasis in rural and urban areas of the Tuscan region, central Italy. J Med Entomol. 2006:43:574-9.

181. Cancrini G, Frangipane Di Regalbono A, Ricci I, Tessarin C, Gabrielli S, Pietrobelli M. Aedes albopictus is a natural vector of Dirofilaria immitis in Italy. Vet Parasitol. 2003;118:195-202.

182. Zittra C, Kocziha Z, Pinnyei S, Harl J, Kieser K, Laciny A, et al. Screening blood-fed mosquitoes for the diagnosis of filarioid helminths and avian malaria. Parasit Vectors. 2015;8:16.

183. Bocková E, Rudolf I, Kočišová A, Betášová L, Venclíková K, Mendel J, et al. Dirofilaria repens microfilariae in Aedes vexans mosquitoes in Slovakia. Parasitol Res. 2013;112:3465-70.
184. Czajka C, Becker N, Poppert S, Jöst H, Schmidt-Chanasit J, Krüger A. Molecula detection of Setaria tundra (Nematoda: Filarioidea) and an unidentified filarial species in mosquitoes in Germany. Parasit Vectors. 2012;5:14.

185. Silbermayr K, Eigner B, Duscher GG, Joachim A, Fuehrer HP. The detection of different Dirofilaria species using direct PCR technique. Parasitol Res. 2014;113:513-6.

186. Kronefeld M, Werner D, Kampen H. PCR identification and distribution of Anopheles daciae (Diptera, Culicidae) in Germany. Parasitol Res. 2014;113: 2079-86.

187. Schaffner F, Mathis A. Dengue and dengue vectors in the WHO European region: past, present, and scenarios for the future. Lancet Infect Dis. 2014;14 1271-80.

188. Kuzmin Y, Varodi E, Vasylyk N, Kononko G. Experimental infection of mosquitoes with Dirofilaria repens (Nematoda, Filarioidea) larvae. Vestn Zool. 2005;39:19-24.

189. Cancrini G, Pietrobelli M, Frangipane di Regalbono A, Tampieri MP, della Torre A. Development of Dirofilaria and Setaria nematodes in Aedes albopictus. Parassitologia. 1995;37:141-5.

190. Cheong WH, Ben Omar AH. Some early findings on the possibility of using Aedes togoi as a vector of Dirofilaria repens in the laboratory. Med J Malaya. 1966;20:332.

191. Silaghi C, Beck R, Capelli G, Montarsi F, Mathis A. Development of Dirofilaria immitis and Dirofilaria repens in Aedes japonicus and Aedes geniculatus. Parasit Vectors. 2017;10:94

192. Sulaiman I. Development of Dirofilaria repens in Aedes aegypti reared in contrasting habitat. Southeast Asian J Trop Med Public Health. 1983;14:122-6.

193. Sulaiman I. Susceptibility of Aedes aegypti to infections with Dirofilaria immitis and Dirofilaria repens. Southeast Asian J Trop Med Public Health. 1983;14:543-7.

194. Christensen BM. Dirofilaria immitis: effect on the longevity of Aedes trivittatus. Exp Parasitol. 1978:44:116-23.

195. Christensen BM, Li J, Chen CC, Nappi AJ. Melanization immune responses in mosquito vectors. Trends Parasitol. 2005;21:192-9.

196. Cancrini G, Coluzzi M, Balbo T, Gallo MG. Seasonal variations in microfilarema and effects of ambient temperature in dogs parasitized by Dirofilaria repens. Parassitologia. 1975:17:75-82.

197. Coluzzi M, Concetti A, Ascoli F. Effect of cibarial armature of mosquitoes (Diptera, Culicidae) on blood-meal haemolysis. J Insect Physiol. 1982;28:885-8.

198. Clements AN. The biology of Mosquitoes: Development, Nutrition and Reproduction, vol. 1. London: Chapman \& Hall; 1992.

199. Bredal WP, Gjerde B, Eberhard ML, Aleksandersen M, Wilhelmsen DK, Mansfield LS. Adult Dirofilaria repens in a subcutaneous granuloma on the chest of a dog. J Small Anim Pract. 1998;39:595-7.

200. Hargis AM, Lewis TP, Duclos DD, Loeffler DG, Rausch RI. Dermatitis associated with microfilariae (Filarioidea) in 10 dogs. Vet Dermatol. 1999;10:95-107.

201. Rocconi F, Di Tommaso M, Traversa D, Palmieri C, Pampurini F, Boari A. Allergic dermatitis by Dirofilaria repens in a dog: clinical picture and treatment. Parasitol Res. 2012;111:493-6.

202. Agapito D, Aziz N-AA, Wang T, Morgan ER, Wright I. Subconjunctival Dirofilaria repens infection in a dog resident in the UK. J Small Anim Pract. 2018:59:50-2.

203. Mircean M, lonică AM, Mircean V, Györke A, Codea AR, Tăbăran FA, et al Clinical and pathological effects of Dirofilaria repens and Dirofilaria immitis in a dog with a natural co-infection. Parasitol Int. 2017;66:331-4.

204. Ferri $E$, Bain O, Barbuto M, Martin C, Lo N, Uni S, et al. New insights into the evolution of Wolbachia infections in filarial nematodes inferred from a large range of screened species. PLoS One. 2011;6:e20843.

205. Bazzocchi C, Genchi C, Paltrinieri S, Lecchi C, Mortarino M, Bandi C. Immunological role of the endosymbionts of Dirofilaria immitis: the Wolbachia surface protein activates canine neutrophils with production of IL-8. Vet Parasitol. 2003;117:73-83.

206. Brattig NW, Racz P, Hoerauf A, Büttner DW. Strong expression of TGF-beta in human host tissues around subcutaneous Dirofilaria repens. Parasitol Res. 2011:108:1347-54

207. Mišić S, Stajković N, Tešić M, Mišić Z, Lj L. Human dirofilariosis in Yugoslavia: report on three cases of Dirofilaria repens infection. Parassitologia. 1996:38:358.

208. Mrad K, Romani-Ramah S, Driss M, Bougrine F, Hechiche M, Maalej M, et al. Mammary dirofilariasis. Int J Surg Pathol. 1999:7:175-8.

209. Petrocheilou V, Theodorakis M, Williams J, Prifti H, Georgilis K, Apostolopoulou I, et al. Microfilaremia from a Dirofilaria-like parasite in Greece. Case report. APMIS. 1998;106:315-8. 
210. Sergiev V, Suprjaga V, Morozov E, LA J. Human dirofilariasis: diagnosis and character of the relationship between causative agent and host. Med Parasitol Parasit Dis. 2009;3:3-6.

211. Poppert S, Hodapp M, Krueger A, Hegasy G, Niesen WD, Kern WV, et al. Dirofilaria repens infection and concomitant meningoencephalitis. Emerg Infect Dis. 2009;15:1844-6.

212. Negahban S, Daneshbod Y, Atefi S, Daneshbod K, Sadjjadi SM, Hosseini SV, et al. Dirofilaria repens diagnosed by the presence of microfilariae in fine needle aspirates. Acta Cytol. 2007;51:567-70.

213. Potters I, Vanfraechem G, Bottieau E. Dirofilaria repens nematode infection with microfilaremia in traveler returning to Belgium from Senegal. Emerg Infect Dis. 2018;24:1761-3.

214. Hempel F, Poppert S, Böker T, Schaaf B. 75-year-old woman with symptoms of the eye. Dtsch Med Wochenschr. 2012;137:1641-2 (In German).

215. Antolová D, Miterpáková M, Paraličová Z. Case of human Dirofilaria repens infection manifested by cutaneous larva migrans syndrome. Parasitol Res. 2015;114:2969-73.

216. Sassi SH, Abid L, Dhouib R, Mrad K, Bouguila H, Abbes I, et al. Conjunctival dirofilariasis due to Dirofilaria repens. A new Tunisian case. J Fr Ophtalmol. 2006;29:e5 (In French).

217. Ziadi S, Trimeche M, Mestiri S, Mokni M, Trabelsi A, Ben Abdelkader A, et al. Human subconjunctival dirofilariasis: two Tunisian case studies. J Fr Ophtalmol. 2005;28:773 (In French).

218. Chazan B, Scherbakov A, Kerner H, Raz R. Autochthonous subcutaneous dirofilariasis in Israel. Harefuah. 2001;140:1125-6 (In Hebrew).

219. Khoramnia R, Wegner A. Images in clinical medicine: subconjunctival Dirofilaria repens. N Engl J Med. 2010;363:e37.

220. Gorezis S, Psilla M, Asproudis I, Peschos D, Papadopoulou C, Stefaniotou M. Intravitreal dirofilariasis: a rare ocular infection. Orbit. 2006;25:57-9.

221. Kirillov DF, Tarasov AV, Shevchuk EA, Matina ON. Observation of dirofilariosis in the practical work of the otorhinolaryngologist. Vestn Otorinolaringol. 2011;5:70-1 (In Russian).

222. Chopra R, Bhatti SM, Mohan S, Taneja N. Dirofilaria in the anterior chamber: a rare occurrence. Middle East Afr J Ophthalmol. 2012;19:349-51.

223. Maltezos ES, Sivridis EL, Giatromanolaki AN, Simopoulos CE. Human subcutaneous dirofilariasis: a report of three cases manifesting as breast or axillary nodules. Scot Med J. 2002;47:86-8.

224. Dujic M, Mitrovic B, Zec I. Orbital swelling as a sign of live Dirophilaria repens in subconjunctival tissue. Scand J Infect Dis. 2003;35:430-1.

225. Tzanetou K, Gogou C, Giannoulopoulos A, Patralexis C, Fragia K. Fibrous subcutaneous nodule caused by Dirofilaria repens. Travel Med Infect Dis. 2009;7:318-22.

226. Mannino G, Contestabile MT, Medori EM, Mannino C, Enrici MM, Marangi M, et al. Dirofilaria repens in the eyelid: case report of subcutaneous manifestation. Eur J Ophthalmol. 2009;19:475-7.

227. Dang TCT, Nguyen TH, Do TD, Uga S, Morishima Y, Sugiyama H, et al. A human case of subcutaneous dirofilariasis caused by Dirofilaria repens in Vietnam: histologic and molecular confirmation. Parasitol Res. 2010;107: 1003-7.

228. Kombade SP, Mantri RS, Ambhore NA, Karyakarte RP. Subcutaneous human dirofilariasis in Vidarbha. Indian J Pathol Microbiol. 2015;58:387-8.

229. Tilakaratne WM, Pitakotuwage TN. Intra-oral Dirofilaria repens infection: report of seven cases. J Oral Pathol Med. 2003;32:502-5.

230. Kaouech E, Becheur M, Cheikh M, Belhadj S, Kallel K, Chaker E. Dirofilariose souscutanée en Tunisie: une observation à localisation labiale. Santé. 2010;20:47-8.

231. Gopinath TN, Lakshmi KP, Shaji PC, Rajalakshmi PC. Periorbital dirofilariasis clinical and imaging findings: live worm on ultrasound. Indian J Ophthalmol. 2013;61:298-300.

232. Siepmann K, Wannke B, Neumann D, Rohrbach JM. Subcutaneous tumor of the lower eyelid: a potential manifestation of a Dirofilaria repens infection. Eur J Ophthalmol. 2005;15:129-31.

233. Avdiukhina TI, Supriaga VG, Postnova VF, Kuimova RT, Mironova NI, Murashov $N E$, et al. Dirofilariasis in the countries of the CIS: an analysis of the cases over the years 1915-1996. Med Parazitol (Mosk). 1997;4:3-7 (In Russian).

234. Desai RS, Pai N, Nehete AP, Singh JS. Oral dirofilariasis. Indian J Med Microbiol. 2015;33:593-4

235. Shenoi S, Kumar P, Khadilkar U. Crusted papule on forehead due to Dirofilaria repens. Trop Doct. 2005;35:181-2.

236. Saied W, Amara K, Bouchoucha S, Khaled S, Mrad K, Nessib MN, et al. Une étiologie inhabituelle de nodule de la main: la dirofilariose péritendineuse. Chir Main. 2010;30:66-8.
237. Chan CC, Kermanshahi MS, Mathew B, England RJ. A rare case of Dirofilaria repens infection. J Laryngol Otol. 2013;127:607-9.

238. Fernando SD, Ihalamulla RL, De Silva WA. Male and female filarial worms Dirofilaria (Nochtiella) repens recovered from the scrotum. Ceylon Med J. 2000;45:131-2.

239. Pampiglione S, Fioravanti ML, Piccolotti D, Pizzicannella G, Reale D. Human dirofilariasis in Italy: a new case in the spermatic cord. Parassitologia. 2002; 44:93-6.

240. Ng WK, Siu TH, Fung B, Kong JHB. Dirofilariasis of breast: report of two cases diagnosed by fine-needle aspiration biopsy. Diagn Cytopathol. 2002;26:22-5.

241. Soussi A, Farah Klibi F, Zermani R, Rammeh S, Ismail O, Zakraoui A, et al. Subcutaneous dirofilariasis due to Dirofilaria repens in Tunisia: a case involving the scrotum. Med Trop (Mars). 2004;64:375-8.

242. Pampiglione S, Orihel TC, Gustinelli A, Gatzemeier W, Villani L. An unusual parasitological finding in a subcutaneous mammary nodule. Pathol Res Pract. 2005;201:475-8.

243. Fleck R, Kurz W, Quade B, Geginat G, Hof H. Human dirofilariasis due to Dirofilaria repens mimicking a scrotal tumor. Urology. 2009;73:209.e1-3.

244. D'Amuri A, Senatore SA, Carlà TG, Floccari F, Villani E, Leocata P, et al. Cutaneous dirofilariasis resulting in orchiectomy. J Cutan Pathol. 2012;39:304-5.

245. Vucaj Cirilovic V, Dobrosavljev M, Niciforovic D, Donat D, BogdanovicStojanovic D, Jukovic M. Dirofilariasis of the breast: sonographic appearance. J Clin Ultrasound. 2014;42:433-5.

246. Rivasi F, Boldorini R, Criante P, Leutner M, Pampiglione S. Detection of Dirofilaria (Nochtiella) repens DNA by polymerase chain reaction in embedded paraffin tissues from two human pulmonary locations. APMIS. 2006;114:567-74.

247. Gros P, Pierre C, Cavallo JD, Carloz E, Camparo P, Arborio M. Subcutaneous Dirofilaria repens dirofilariasis. Arch Anat Cytol Pathol. 1996;44:272-7.

248. Manfredi M, Di Cerbo A, Genchi M. Biology of filarial worms parasitizing dogs and cats. In: Genchi C, Rinaldi L, Cringoli G, editors. Mappe Parassitologiche 8. Dirofilaria immitis and D. repens in dog and cat and human infections. 1st ed. Naples: Rolando Ed; 2007. p. 41-5.

249. Euzeby J. Diagnostic expérimental des helminthoses animales: animaux domestiques, animaux de laboratoire, primates; travaux pratiques d'helminthologie vétérinaire: livre 1 généralités, diagnostic ante-mortem. Paris: Informations Techniques des Services Vétérinaires; 1981. p. 349.

250. Gardiner CH, Poynton SL. An Atlas of Metazoan Parasites in Animal Tissues. Washington, DC: Armed Forces Institute of Pathology, American Registry of Pathology; 1999.

251. Giori L, Garbagnoli V, Venco L, Genchi M, Bazzocchi C, Bertazzolo W. What is your diagnosis? Fine-needle aspirate from a subcutaneous mass in a dog. Mixed neutrophilic-eosinophilic inflammation with Dirofilaria fragments. Vet Clin Pathol. 2010;39:255-6.

252. Ionică AM, Matei IA, D'Amico G, Bel LV, Dumitrache MO, Modrý D, et al. Dirofilaria immitis and $D$. repens show circadian co-periodicity in naturally co-infected dogs. Parasit Vectors. 2017;10:116.

253. Demiaszkiewicz AW, Polańczyk G, Osińska B, Pyziel AM, Kuligowska I, Lachowicz J. Morphometric characteristics of Dirofilaria repens Railliet et Henry, 1911 parasite of dogs in Poland. Wiadom Parazytol. 2011;57:253-6.

254. Magnis J, Lorentz S, Guardone L, Grimm F, Magi M, Naucke TJ, et al. Morphometric analyses of canine blood microfilariae isolated by the Knott's test enables Dirofilaria immitis and D. repens species-specific and Acanthocheilonema (syn. Dipetalonema) genus-specific diagnosis. Parasit Vectors. 2013;6:48.

255. Gioia G, Lecová L, Genchi M, Ferri E, Genchi C, Mortarino M. Highly sensitive multiplex PCR for simultaneous detection and discrimination of Dirofilaria immitis and Dirofilaria repens in canine peripheral blood. Vet Parasitol. 2010;172:160-3.

256. Albonico F, Loiacono M, Gioia G, Genchi C, Genchi M, Mortarino M. Rapid differentiation of Dirofilaria immitis and Dirofilaria repens in canine peripheral blood by real-time PCR coupled to high resolution melting analysis. Vet Parasitol. 2014;200:128-32.

257. Hodžić A, Alić A, Fuehrer H-P, Harl J, Wille-Piazzai W, Duscher G. A molecular survey of vector-borne pathogens in red foxes (Vulpes vulpes) from Bosnia and Herzegovina. Parasit Vectors. 2015;8:88.

258. Masny A, Sałamatin R, Rozej-Bielicka W, Golab E. Is molecular xenomonitoring of mosquitoes for Dirofilaria repens suitable for dirofilariosis surveillance in endemic regions? Parasitol Res. 2016;115:511-25.

259. Rishniw M, Barr SC, Simpson KW, Frongillo MF, Franz M, Dominguez Alpizar $J$. Discrimination between six species of canine microfilariae by a single polymerase chain reaction. Vet Parasitol. 2006;135:303-14. 
260. Latrofa MS, Weigl S, Dantas-Torres F, Annoscia G, Traversa D, Brianti E, et al. A multiplex PCR for the simultaneous detection of species of filarioids infesting dogs. Acta Trop. 2012;122:150-4.

261. Manzocchi S, Venco L, Piseddu E, Pantchev N, Masserdotti C, Bonfanti U, et al. Positive PCR alone should not be considered sufficient to establish Dirofilaria repens as the cause of subcutaneous nodular lesions in the absence of a clear cytologic picture. Vet Clin Pathol. 2017;46:389-90.

262. KKW T, Wong SSY, Poon RWS, Trendell-Smith NJ, Ngan AHY, Lam JWK, et al. A novel Dirofilaria species causing human and canine infections in Hong Kong. J Clin Microbiol. 2012;50:3534-41.

263. Mirahmadi H, Maleki A, Hasanzadeh R, Ahoo MB, Mobedi I, Rostami A. Ocular dirofilariasis by Dirofilaria immitis in a child in Iran: a case report and review of the literature. Parasitol Int. 2017;66:978-81.

264. Orihel T, Ash L. Dirofilaria species - Parasites in Human Tissues. 1st ed. Chicago: American Society of Clinical Pathologists; 1995.

265. Kwok RPW, Chow PPC, Lam JKM, Fok AC-T, Jhanji V, Wong WWY, et al. Human ocular dirofilariasis in Hong Kong. Optom Vis Sci. 2016;93:545-8.

266. Rossi L, Ferroglio E, Agostini A. Use of moxidectin tablets in the control of canine subcutaneous dirofilariosis. Vet Rec. 2002;150:383.

267. Rossi L, Ferroglio E, Agostini A. Use of an injectable, sustained-release formulation of moxidectin to prevent canine subcutaneous dirofilariosis. Vet Rec. 2004;154:26-7.

268. Fok É, Jacsó O, Szebeni Z, Gyorffy A, Sükösd L, Lukács Z, et al. Elimination of Dirofilaria (syn. Nochtiella) repens microfilariae in dogs with monthly treatments of moxidectin 2.5\%/imidacloprid 10\% (Advocate ${ }^{\oplus}$, Bayer) spoton. Parasitol Res. 2010;106:1141-9.

269. Genchi M, Pengo G, Genchi C. Efficacy of moxidectin microsphere sustained release formulation for the prevention of subcutaneous filarial (Dirofilaria repens) infection in dogs. Vet Parasitol. 2010;170:167-9.

270. Hellmann K, Heine J, Braun G, Paran-Dobesova R, Svobodova V. Evaluation of the therapeutic and preventive efficacy of $2.5 \%$ moxidectin $/ 10 \%$ imidacloprid (Advocate ${ }^{\oplus}$, Bayer Animal Health) in dogs naturally infected or at risk of natural infection by Dirofilaria repens. Parasitol Res. 2011;109:77-86.

271. Genchi C, Genchi M, Petry G, Kruedewagen EM, Schaper R. Evaluation of the efficacy of imidacloprid $10 \%$ / moxidectin $2.5 \%$ (Advocate ${ }^{\circledast}$, Advantage ${ }^{\circledast}$ multi, Bayer) for the prevention of Dirofilaria repens infection in dogs. Parasitol Res. 2013;112(Suppl. 1):81-9.

272. Venco L, McCall JW, Guerrero J, Genchi C. Efficacy of long-term monthly administration of ivermectin on the progress of naturally acquired heartworm infections in dogs. Vet Parasitol. 2004;124:259-68.

273. Giannelli A, Ramos RAN, Traversa D, Brianti E, Annoscia G, Bastelli F, et al. Treatment of Dirofilaria repens microfilariaemia with a combination of doxycycline hyclate and ivermectin. Vet Parasitol. 2013;197:702-4.

274. Kramer L, Genchi C. Where are we with Wolbachia and doxycycline: an in-depth review of the current state of our knowledge. Vet Parasitol. 2014;206:1-4.

275. Genchi C, Poglayen G, Kramer L, Casiraghi M, Venco L, Brianti E. Efficacia di selamectin nella profilassi delle infestazioni da Dirofilaria repens del cane. Veterinaria. 2002;16:69-71.

276. Jacsó O, Fok E, Kiss G, Kökény G, Lang Z. Preliminary findings on the efficacy of selamectin in the treatment of dogs naturally infected with Dirofilaria repens. Acta Vet Hung. 2010;58:405-12.

277. Di Cesare A, Braun G, Di Giulio E, Paoletti B, Aquilino V, Bartolini R, et al. Field clinical study evaluating the efficacy and safety of an oral formulation containing milbemycin oxime/praziquantel (Milbemax ${ }^{\circledast}$, Novartis Animal Health) in the chemoprevention of the zoonotic canine infection by Dirofilaria repens. Parasit Vectors. 2014;7:347.

278. McCall JW, Hodgkins E, Varloud M, Mansour A, DiCosty U. Blocking the transmission of heartworm (Dirofilaria immitis) to mosquitoes (Aedes aegypti) by weekly exposure for one month to microfilaremic dogs treated once topically with dinotefuran-permethrin-pyriproxyfen. Parasit Vectors. 2017; 10(Suppl. 2):511.

279. Ciuca L, Simòn F, Rinaldi L, Kramer L, Genchi M, Cringoli G, et al. Seroepidemiological survey of human exposure to Dirofilaria spp. in Romania and Moldova. Acta Trop. 2018;187:169-74.

280. Diaz JH. Increasing risks of human dirofilariasis in travelers. J Travel Med. 2015;22:116-23.

281. Semenza JC, Menne B. Climate change and infectious diseases in Europe. Lancet Infect Dis. 2009;9:365-75.

282. Wilson N, Lush D, Baker MG. Meteorological and climate change themes at the 2010 International Conference on Emerging Infectious Diseases. Euro Surveill. 2010;15:19627.
283. Tippelt $L$, Walther $D$, Kampen $H$. The thermophilic mosquito species Uranotaenia unguiculata Edwards, 1913 (Diptera: Culicidae) moves north in Germany. Parasitol Res. 2017;116:3437-40.

284. Genchi C, Rinaldi L, Mortarino M, Genchi M, Cringoli G. Climate and Dirofilaria infection in Europe. Vet Parasitol. 2009;163:286-92.

285. Genchi C, Mortarino M, Rinaldi L, Cringoli G, Traldi G, Genchi M. Changing climate and changing vector-borne disease distribution: the example of Dirofilaria in Europe. Vet Parasitol. 2011;176:295-9.

286. Sabatini A, Raineri V, Trovato G, Coluzzi M. Aedes albopictus in Italy and possible diffusion of the species into the Mediterranean area. Parassitologia. 1990;32:301-4.

287. Petrić D, Zgomba M, Bellini R, Becker N. Surveillance of mosquito populations - a key element to understanding the spread of invasive vector species and vector-borne diseases in Europe. In: Hauppauge MD, editor. Essays on Fundamental and Applied Environmental Topics. New York: Nova Science Publishers; 2012. p. 192-224.

288. Trotz-Williams LA, Trees AJ. Systematic review of the distribution of the major vector-borne parasitic infections in dogs and cats in Europe. Vet Rec. 2003;152:97-105.

289. Magi M, Calderini P, Gabrielli S, Dell'Omodarme M, Macchioni F, Prati MC, et al. Vulpes vulpes: a possible wild reservoir for zoonotic filariae. Vector Borne Zoonotic Dis. 2008;8:249-52

290. Svobodova V, Misonova P. The potential risk of Dirofilaria immitis becoming established in the Czech Republic by imported dogs. Vet Parasitol. 2005;128: 137-40.

291. Duscher G, Feiler A, Wille-Piazzai W, Bakonyi T, Leschnik M, Miterpáková M, et al. Detection of Dirofilaria in Austrian dogs. Berl Munch Tierarztl Wochenschr. 2009;122:199-203.

292. Tolnai Z, Széll Z, Sproch Á, Szeredi L, Sréter T. Dirofilaria immitis: an emerging parasite in dogs, red foxes and golden jackals in Hungary. Vet Parasitol. 2014;203:339-42.

293. Dantas-Torres F, Otranto D. Dirofilariosis in the Americas: a more virulent Dirofilaria immitis? Parasit Vectors. 2013;6:288.

294. Piergili Fioretti D, Diaferia M, Grelloni V, Maresca C. Canine filariosis in Umbria: an update of the occurrence one year after the first observation of autochthonous foci. Parassitologia. 2003;45:79-83.

295. Tasić A, Rossi L, Tasić S, Miladinović-Tasić N, llić T, Dimitrijević S. Survey of canine dirofilariasis in Vojvodina. Serbia. Parasitol Res. 2008;103:1297-302.

296. Giannetto S, Poglayen G, Gaglio G, Brianti E. Prevalence and epidemiological aspects of microfilaraemia in dogs in Sicily. In: Abstract book of the 1st European Dirofilaria days. Zagreb; 2007.

\section{Ready to submit your research? Choose BMC and benefit from:}

- fast, convenient online submission

- thorough peer review by experienced researchers in your field

- rapid publication on acceptance

- support for research data, including large and complex data types

- gold Open Access which fosters wider collaboration and increased citations

- maximum visibility for your research: over $100 \mathrm{M}$ website views per year

At $\mathrm{BMC}$, research is always in progress.

Learn more biomedcentral.com/submissions 